\title{
Chronic viral infections in myalgic encephalomyelitis/chronic fatigue syndrome (ME/CFS)
}

\author{
Santa Rasa', Zaiga Nora-Krukle ${ }^{1}$, Nina Henning², Eva Eliassen² ${ }^{0}$, Evelina Shikova ${ }^{4}$, Thomas Harrer ${ }^{5}$, \\ Carmen Scheibenbogen ${ }^{6}$, Modra Murovska ${ }^{1}$ and Bhupesh K. Prusty ${ }^{2,3^{*}} \mathbb{B}$ on behalf of the European Network \\ on ME/CFS (EUROMENE)
}

\begin{abstract}
Background and main text: Myalgic encephalomyelitis/chronic fatigue syndrome (ME/CFS) is a complex and controversial clinical condition without having established causative factors. Increasing numbers of cases during past decade have created awareness among patients as well as healthcare professionals. Chronic viral infection as a cause of ME/CFS has long been debated. However, lack of large studies involving well-designed patient groups and validated experimental set ups have hindered our knowledge about this disease. Moreover, recent developments regarding molecular mechanism of pathogenesis of various infectious agents cast doubts over validity of several of the past studies.

Conclusions: This review aims to compile all the studies done so far to investigate various viral agents that could be associated with ME/CFS. Furthermore, we suggest strategies to better design future studies on the role of viral infections in ME/CFS.
\end{abstract}

Keywords: ME/CFS, Viral infections, Biomarkers

\section{Background}

Myalgic encephalomyelitis/chronic fatigue syndrome (ME/CFS) is a disease that causes central nervous system (CNS) and immune system disturbances, cell energy metabolisms and ion transport dysfunction, as well as cardiovascular problems, gastrointestinal dysfunction, cognitive impairment, myalgia, arthralgia, orthostatic intolerance, inflammation and innate immunity disturbances. The main clinical sign is persisting chronic fatigue, which is not relieved by rest and lasts for more than 6 months [1]. A large group of patients remains wheelchair-dependent and many remain housebound or even bedbound [2].

ME/CFS is sporadic with occasional outbreaks [3]. Currently around $80 \%$ of $\mathrm{ME} / \mathrm{CFS}$ cases are undiagnosed

\footnotetext{
*Correspondence: bhupesh.prusty@uni-wuerzburg.de

${ }^{3}$ Institute for Virology and Immunobiology, Würzburg, Germany

Full list of author information is available at the end of the article
}

[4]. According to the available literature, already back in 2009 around 17 million people were diagnosed with this disease, including 800,000 patients in the United States of America and 240,000 in the United Kingdom [5]. Etiological factors for ME/CFS include genetic predisposition, stress, trauma, exposure to toxins, physical activity and rest ratio, as well as a recent history of infectious disease [2]. Females within the age group of 30-39 years are more prone to this disease [6]. Nevertheless, ME/CFS can affect individuals from all races, genders, age groups and social statuses. Population studies show that the prevalence of ME/CFS worldwide is from $0.2 \%$ of clinically diagnosed up to $3.48 \%$ of self-reported population depending on the applied diagnostic criteria. Most of the patients with ME/CFS suffer from long lasting symptoms, with only $6 \%$ of patients experiencing remission of the disease [7-9]. ME/CFS symptoms range from long lasting fatigue, memory loss, difficulty concentrating, sore throat, lymphadenopathy, muscle pain, headaches 
and un-refreshing sleep to extreme fatigue after exertion. The pathomechanisms of ME/CFS are still unknown, and there are no standardized biological markers or tests for diagnostics; therefore, even the existence of this medical diagnosis has been questioned for long time [10].

During the past 2 decades, few illnesses have been as extensively discussed as chronic fatigue syndrome (CFS). A consensus for the proper diagnostic definition for CFS was reached in 1994 on a case definition from the United States Centers for Disease Control and Prevention [11]. Therefore, prolonged fatigue is defined as self-reported, persistent fatigue lasting 1 month whereas chronic fatigue is persistent or relapsing fatigue lasting 6 months or longer [11]. Later in 2011 International Consensus Panel (ICP) developed International Consensus Criteria suggesting that this disease is to be defined as myalgic encephalomyelitis (ME) due to neuropathological inflammation [12].

Clinical evaluation for identifying underlying or contributing conditions of chronic fatigue is required before further diagnosis or classifications can be made. Besides persistent post-exertional fatigue, ME/CFS is characterized by substantial symptoms related to cognitive, immune and autonomous dysfunctions [13, 14]. Though $\mathrm{ME} / \mathrm{CFS}$ is a chronic illness of uncertain cause with unknown pathogenesis, there is abundant evidence of an underlying biological process. Since sudden disease outbreaks in patients start with a "flu-like" illness, it seems plausible that an infectious agent can trigger the syndrome. In fact, viral-like illnesses appear to precede ME/ CFS onset in approximately $50 \%$ of patients [15]. In addition, there are indications that immunological dysfunction may contribute to the emergence of symptoms [16].

The pathogenesis of ME/CFS is likely multi-factorial and various microbial and viral infections are considered to be the possible trigger factors of ME/CFS. The illness has been frequently accompanied with various viral infections and studies have been conducted on association of ME/CFS with Epstein-Barr virus (EBV) [17, 18], cytomegalovirus (CMV) [19], human herpesvirus (HHV) 6, HHV-7, HHV-8 [20-22], human parvovirus B19 (B19V), enteroviruses [23], lentivirus [24] and bacteria as mycoplasma [25], Lyme disease causing borrelia, Q fever causing Coxiella burnetii [26] and other pathogens.

Still, the association of ME/CFS with a single infectious agent has not been confirmed, and the role of viral infections in ME/CFS remains obscure [2, 27]. This may be attributed to the small size and/or heterogeneity of studied ME/CFS populations, not well-characterized ME/CFS patients, lack of adequate controls, high prevalence of persistent viral infection in the general population, different methodological approaches applied and so on. Here we present an overview of studies addressing the possible association of viral infections with ME/CFS, focusing on human herpesviruses, B19V, and enteroviruses, which all can trigger ME/CFS. These viruses, after an acute infection, remain in the body as mostly latent, persistent infections and may reactivate under various conditions. Immunologic disturbance associated with ME/CFS may be the result of viral infection or may lead to reactivation of latent viruses. Once reactivated, the viruses may contribute to the morbidity of ME/CFS via inflammation and immune dysregulation, especially the herpesviruses EBV and HHV-6, which infect immune cells [28]. Viral infections can trigger an autoimmune response as well [29]. In the majority of ME/CFS cases, there is no conclusive evidence for chronic viral infection, but it is plausible that viruses could act via a "hit and run" mechanism; this theory proposes that viruses trigger the disease, cause immune abnormalities and leave a dysfunctional immune system and/or autoimmunity.

\section{Human herpesviruses}

According to the International Committee on Taxonomy of Viruses, Herpesviridae family includes Alphaherpesvirinae, Betaherpesvirinae and Gammaherpesvirinae subfamilies. Currently there are nine human herpesviruses: herpes simplex virus (HSV)-1, HSV-2, varicella zoster virus (VZV), EBV, CMV, HHV-6A, HHV-6B, HHV-7, HHV-8. HHV-6 and HHV-7, members of the Herpesviridae family, Beta-herpesvirinae subfamily, Roseolovirus genus, are most studied human pathogens in association with ME/CFS [30]. HHV-6A was first isolated in 1986 from peripheral blood mononuclear cells (PBMCs) of patients with acquired immunodeficiency syndrome (AIDS) and lympholeukosis [31]. HHV-7 was first isolated in 1990 from CD4 ${ }^{+}$lymphocytes of healthy adult [32]. Primary infection with these viruses usually is observed in early childhood-from age of 6 months to 3 years. They can cause Roseola infantum or Exanthema subitum with fever, rashes and elevated body temperature lasting for 3 to 5 days. In addition, it can affect several organ systems, including CNS [33]. Likewise, infection course can be asymptomatic [34]. HHV-6B and HHV-7 are widespread and prevalence is more than $90 \%$ of general population [35]. The seroprevalence of HHV-6A is unknown. However one study of Chinese individuals put the prevalence at $11 \%$ of controls [36]. One feature of all herpesviruses is that they can establish a lifelong persistent infection termed latency [37]. Latent HHV-6 can reside in a dormant state inside human host cells by integrating viral genome into telomeric ends of host cell chromosomes (ciHHV-6) [38]. Recently also chromosomal integration of HHV-7 into the host genome was discovered [39]. During latency, minimal viral transcription and no production of infectious virions occurs, 
resulting in no detectable clinical complications. However, activated forms of HHV-6A/B and HHV-7 are known to have immunomodulating properties such as modulating the expression of several cytokines and chemokines or inducing immunosuppression by triggering apoptosis in lymphocytes [40-42]. Since both viruses are ubiquitous, concurrent infection is common and it has also been reported, that $\mathrm{HHV}-7$ can reactivate $\mathrm{HHV}$ 6A/B [43-45].

Reactivation of latent HHV-6A/B can be caused by various stress conditions leading to increased severities of multiple human disorders [46, 47]. Even though evidence is lacking, it is also possible that exposure to certain drugs could reactive ciHHV-6. One known chemical to reactivate HHV-6 in vitro is the HDAC inhibitor Trichostatin A [48]. Similarly two other commonly known pharmaceuticals, sodium valporate and amoxicillin, also enhance HHV-6 replication [49, 50]. Virus reactivation is possible in cases of immune disturbances, long-term stress, immunosuppressive therapy, prolonged anaesthesia, transplantation, AIDS and others [21]. For example, HHV-6A reactivation has been found in patients with multiple sclerosis (MS) [51] and HIV infection [52] and HHV-6B reactivation has occurred in amnesia [53] and hepatitis [54]. The virus can also reactivate in the presence of malignant and non-malignant diseases [55] and HHV-6A antibodies are a risk factor for non-Hodgkin lymphoma [36].

Due to its life-long persistence and its broad tissue tropism, HHV-6 has been speculated to be a possible trigger for ME/CFS. The involvement of herpesviruses in ME/CFS was already considered in 1988, when serological evidence pointed to reactivation of HHV-6 among patients, and a subset of patients were found to exhibit higher levels of antibodies against the EBV viral capsid antigen (VCA) and early antigen (EA) but an absence of antibodies to EBNA [56]. Based on earlier reports and presentations, Ablashi suggested in 1994 that ME/CFS could be a result of immunological disturbances after herpesvirus reactivation [57]. Investigating this hypothesis, Buchwald et al. started the first large study [20], when the case definition for ME/CFS had not yet been made. Their study included 259 patients with ME/CFS symptoms. Serum chemistry tests and polymerase chain reaction (PCR) assays confirmed the finding of active HHV-6 infection in $70 \%$ of patients. Even though they suggested that active replication of HHV-6 represented reactivation of latent infection due to immunologic dysfunction, they did not directly address HHV-6 playing a role in producing ME/CFS symptoms.

Follow-up studies using only serological techniques could not differentiate between active and latent infection $[21,22]$ but revealed a slight tendency to an association between ME/CFS and HHV-6, with a greater prevalence and higher levels of HHV-6-specific antibodies in patients, as well as a greater prevalence of DNA in PBMCs from those with ME/CFS. Notably, in both of these studies, HHV-6A was found to predominate among ME/CFS patients. Moreover, an association between active HHV- 6 infection and ME/CFS has been demonstrated in studies distinguishing between active and latent infection using immunofluorescence assays directed against HHV-6A antigens or early antibody assays $[58,59]$. On the other hand, there are several studies in which both serological techniques as well as PCR-based techniques distinguishing between active and latent infection lead to the conclusion that HHV-6 infection does not correlate with ME/CFS [60, 61]. Chapenko et al. [62] also evaluated whether HHV-6 infections could be the causative agent for ME/CFS. They found active HHV-6 more often in ME/CFS patients than controls, and active infection correlated with the occurrence of the clinical symptoms of ME/CFS, including lymphadenopathy, subfebrility, and malaise after exertion.

The presence of HHV-7 and other HHVs has been determined in patients with ME/CFS. Sairenji et al. revealed $100 \%$ HHV-7 seropositivity among 20 patients [63]. In another study involving 17 ME/CFS patients, HHV-7 reactivation was detected more frequently than HHV- 6 reactivation and concurrent active HHV-6 and HHV-7 infection was accompanied by immunological changes in the form of significantly increased $\mathrm{CD} 95^{+}$ cells, decreased $\mathrm{CD}^{+}$and $\mathrm{CD} 4^{+} \mathrm{T}$ cells, and a lower CD4/CD8 ratio [64]. Active HHV-6, HHV-7 and B19V infection/co-infection was confirmed analysing 108 patients with ME/CFS [62].

However, PCR analysis showed a similarly high detection rate of $\mathrm{HHV}-7$ genomic sequences among patients with ME/CFS and controls (82\% vs $83 \%$ ) [65]. In another study, the percentage of HHV-6, HHV-7 and co-infection was similar between patients and controls; nevertheless, HHV-7 was approximately two times more prevalent than HHV-6, with HHV-6 and HHV-7 DNA detected in the PBMCs of $26.7 \%$ and $69.9 \%$ of healthy adults, respectively, and $35.1 \%$ and $77.3 \%$ of ME/CFS patients [66]. Others found HHV-7 DNA in only $7.7 \%$ of peripheral blood lymphocyte samples from patients with ME/ CFS using PCR [67]. In addition, detection of HHV-7 in a high percentage of gastro-intestinal biopsies from patients (85-92\%) and controls (66-83\%) with quantitative PCR (qPCR) is reported, though without statistical difference between the groups [68]. No difference between severity of symptoms and viral load of HHV-6 and HHV-7 in saliva and PBMC of ME/CFS patients and controls was shown [69]. Besides, detectable reactivation of HHV-6A/6B and HHV-7 in saliva is considered as a 
biomarker for physiological fatigue, and can therefore be used to distinguish between pathological and physiological fatigue [70].

There is no statistically significant difference between reported studies that have found no correlation between HHV-6/HHV-7 infection/co-infection and ME/CFS (in total 17) and publications that noted a correlation (in total 12) $(P=0.2935)$ (Table 1). Nevertheless, some study cohorts are rather small to draw general conclusions about the association of a viral infection with the disease.

Several groups have also reported co-infections of EBV with HHV-6 in ME/CFS patients [63]. Serological analysis has revealed a higher frequency of antibodies to EBV VCA in patients than controls. In addition, these serum antibodies could persist for several years, indicating that immune disturbances may allow viral reactivation [71]. An abnormal immune response to EBV infection has been reported in ME/CFS cases; however, later publication showed no differences of EBV prevalence among patients and controls [72, 73]. Although Manian and colleagues found higher titers of IgG class antibodies against EBV viral capsid antigen in patients than in controls, they did not find a statistically significant difference in titers of antibodies to early antigens of EBV, HSV-1, HSV-2 and HHV-6 in patients compared to healthy controls. Therefore, they did not conclude that there was a significant association between these infections and ME/CFS [74]. Elsewhere, ME/CFS patients' EBV antibody titers were not significantly different compared to controls [75]. In 1991, Landay et al. found antibodies to EBV early antigen significantly more frequently among ME/CFS patients than healthy adults, but they observed equal rates of EBV VCA and EBNA seropositivity among patients and controls [76]. At the same time, other studies showed no correlation between EBV infection, nor CMV infection, and ME/CFS [77, 78]. A very low percentage of EBV-specific IgG class antibodies in patients and controls has been described [79]. Zhang et al. have shown that EBV seroprevalence (VCA IgG) among ME/CFS patients was similar to that of the general population, but VCA IgM titers, EBNA IgG titers, and EBV-related genes were associated with ME/CFS subtypes [80]. Moreover, in this cohort, most ME/CFS patients demonstrated primary infection/reactivation serostatus, while the serostatus of controls most often corresponded to the late phase of EBV infection.

In some reports, EBV was not detected in blood plasma by PCR [61], and no difference was revealed in the frequency of EBV genomic sequences detected in stomach and duodenum biopsies by qPCR [68]. Likewise, other studies using immunofluorescence, enzymelinked immunosorbent assay (ELISA), PCR and western blot have shown that EBV is present, though not significantly more often in patients with ME/CFS than in controls [81-84].

Recently published data also support the hypothesis on herpesviruses involvement in ME/CFS development due to expression of antibodies against herpesvirusesencoded deoxyuridine triphosphate nucleotidohydrolases (dUTPases) that activates humoral immune response [85]; anti-EBV and HHV-6 dUTPase antibodies were present in $55.4 \%$ and $54.06 \%$ of ME/CFS patients in one cohort, respectively. The same study found EBV dUTPase antibodies in $29.09 \%$ of patients and $25.83 \%$ of controls overall from a separate cohort. Compared to controls, the patients had significantly higher anti-EBV dUTPase antibodies.

Serum antibody and genomic sequence analysis of HSV, VZV, EBV, CMV, HHV-6, HHV-7, HHV-8, JC virus, $\mathrm{BK}$ virus, and $\mathrm{B} 19 \mathrm{~V}$ in 22 monozygotic twin pairs, of which one twin met criteria for ME/CFS and the other twin was healthy, revealed no differences between the group of twins with ME/CFS and the healthy twins [61]. Similarly, Cameron and co-workers did not find significant differences in EBV, HHV-6, nor CMV seropositivity and viral loads between $20 \mathrm{ME} / \mathrm{CFS}$ patients and 10 controls using qPCR as well as serological assays for HHV-6 IgG, CMV IgM, and EBV IgG VCA p18, IgG EBNA-1, and IgG EA [83]. Landay et al. also failed to find any serological links between these viruses as well as adenovirus, HTLV I/II, HIV, papovavirus, human spumavirus, rubeola, and coxsackie B4 and the pathogenesis of ME/CFS [76] Elevated IgG titers to CMV were demonstrated in only 6/107 (6\%) patients with $\mathrm{ME} / \mathrm{CFS}$ and only rarely were HSV, coxsackievirus, chlamydia, campylobacter, yersinia or candida infections observed [81]. Likewise, serum analysis revealed no correlation between ME/CFS and CMV, HSV-1, HSV-2 and adenovirus in another report [20]. However, analysis of more ME/CFS patients and controls showed the presence of CMV IgM p52 and CM2 antibodies in $16 / 34$ patients and none of the controls, suggesting an etiologic role of CMV in ME/CFS [86]. HHV-8, which has been infrequently studied in this disease, was found in $2 / 35$ (5.7\%) ME/CFS patients and in $1 / 25$ (4\%) controls [22].

Although an association of ME/CFS with viral infections has not been demonstrated in all studies, ME/ CFS can be triggered by various factors, and infections could contribute to a subgroup of ME/CFS patients [66, 83]. Moreover, autoimmune, immune, metabolic and psychological disturbances could emerge due to infectious disease [2]. 


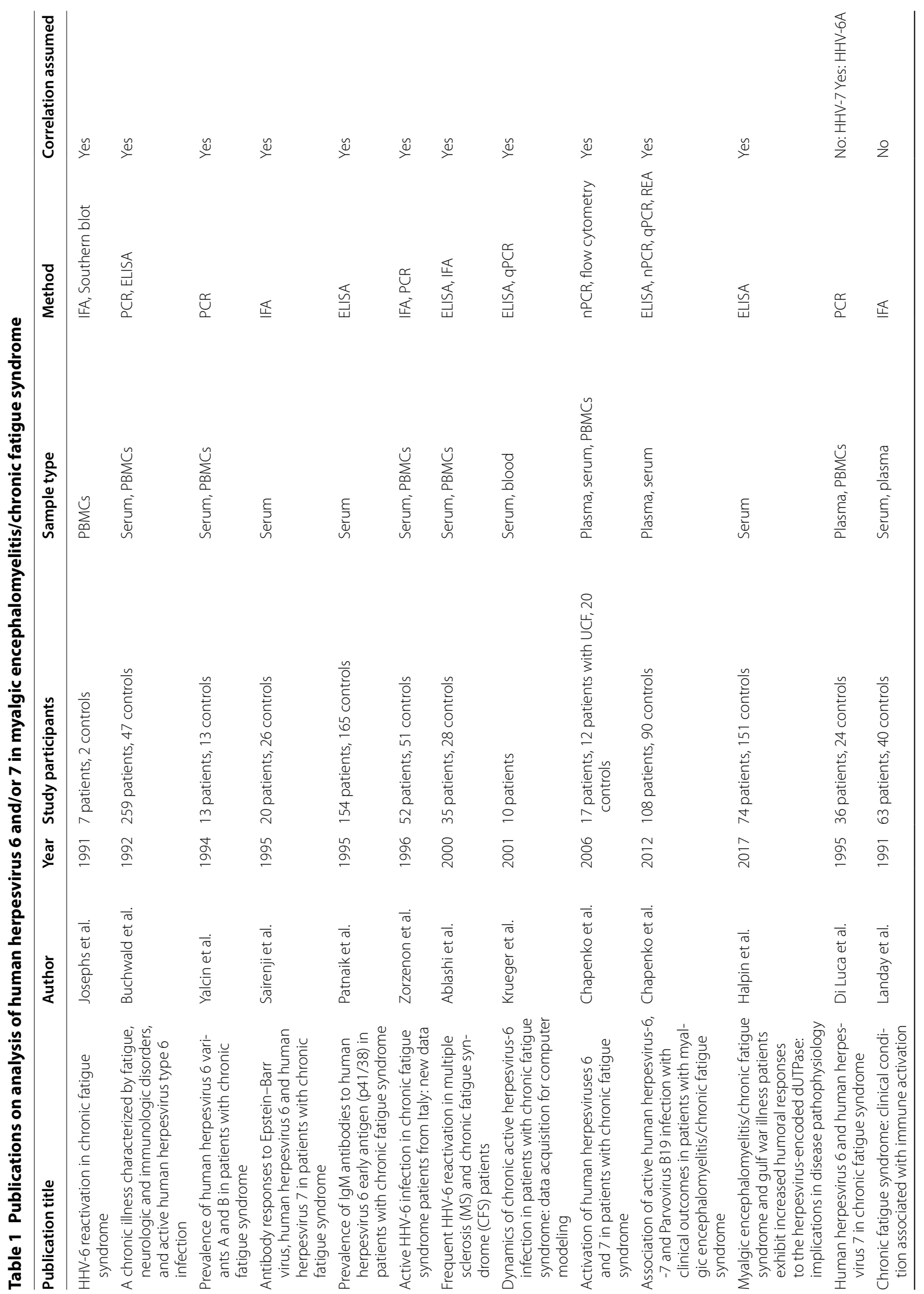


Rasa et al. J TransI Med (2018) 16:268

Page 6 of 25

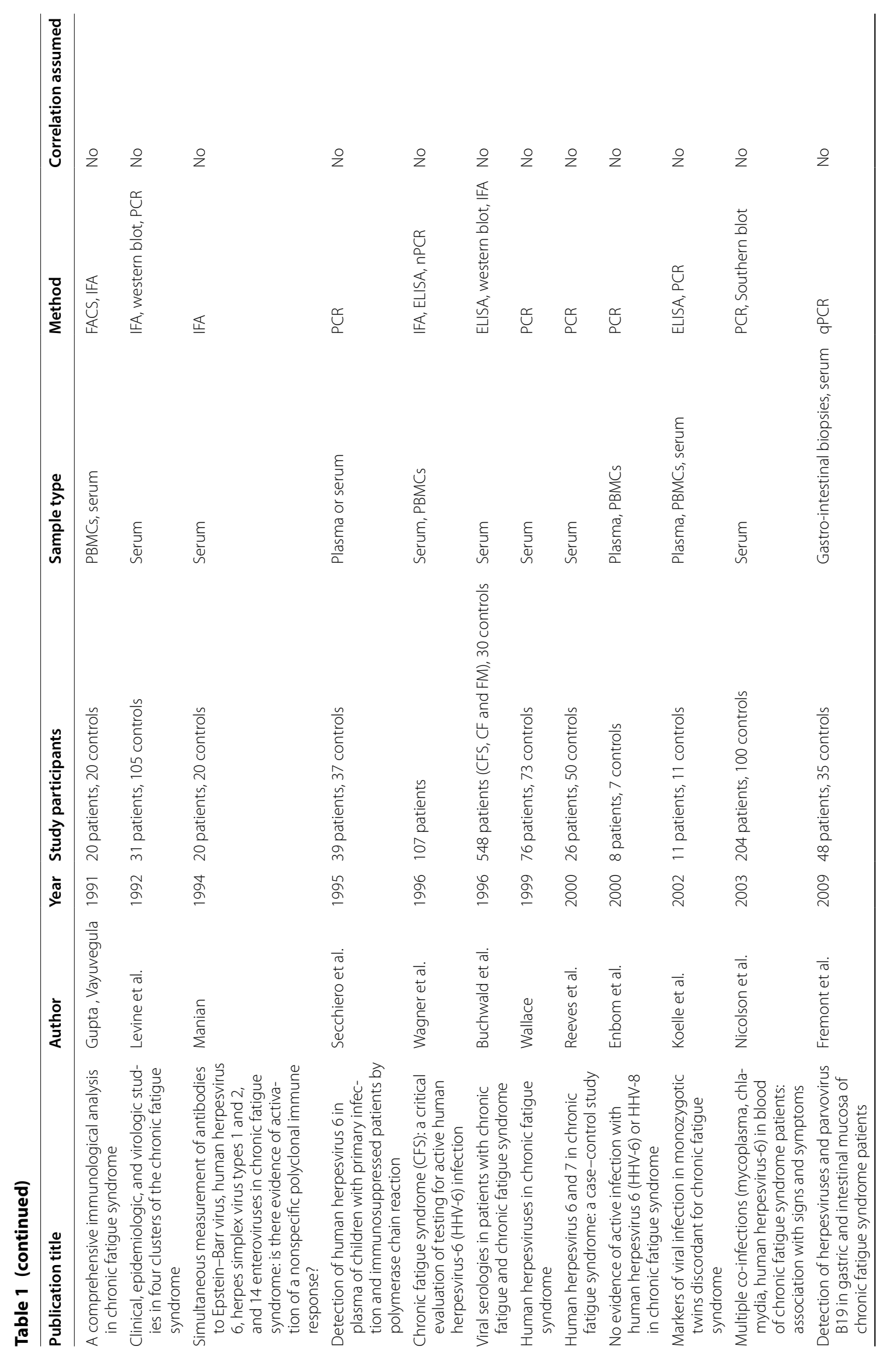




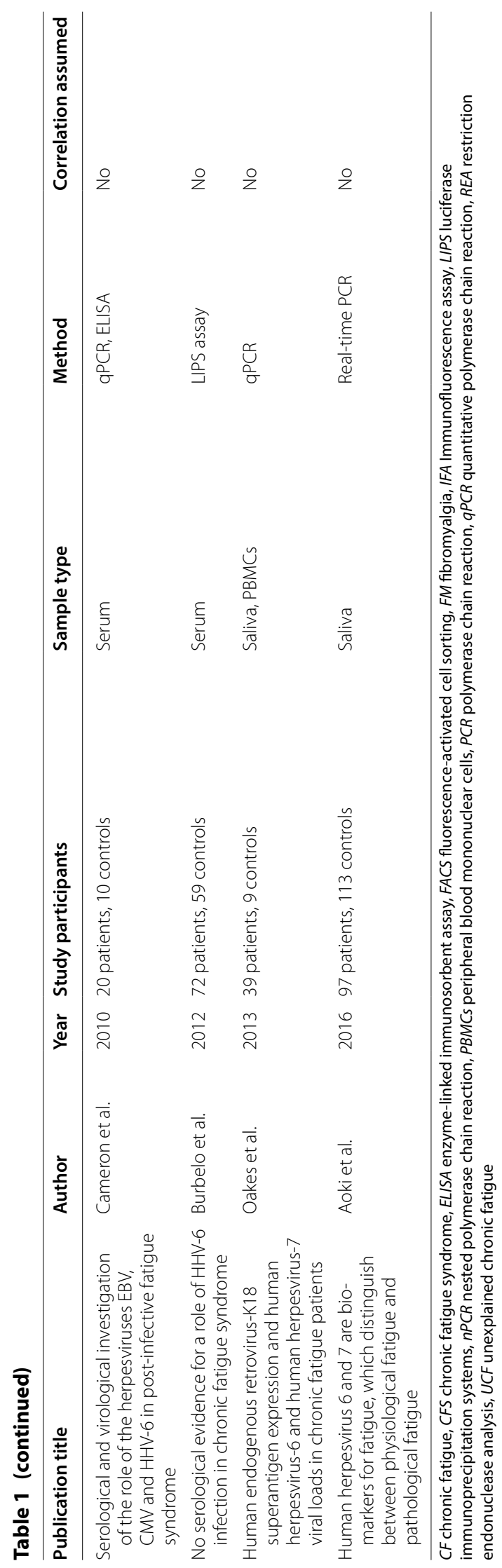




\section{Enteroviruses}

Single-stranded positive-sense RNA viruses from the Enterovirus genus belong to the Picornaviridae family. They comprise a large group of more than 70 different enteroviruses that have the ability to infect humans. Although enteroviral infections in humans are frequently asymptomatic, they can exert a variety of symptoms during acute infections. In addition, chronic enteroviral infections have been implicated in myocarditis [87-89] and in juvenile-onset type-1 diabetes [90].

The role of enterovirus infection as a potential factor in the etiology of ME/CFS has been suspected for about 3 decades. At the same time, it has been largely disputed, as the data from the literature are controversial. RNA of enteroviruses has been found in variety of specimens (blood, stool, gastric and muscle biopsy) from ME/CFS patients more frequently compared to control subjects (Table 2). Clements et al. detected enterovirus-specific sequences in $36 / 88(41 \%)$ serum samples from chronic fatigue patients, $22 / 82$ (27\%) acutely ill individuals, and $3 / 126(2.4 \%)$ healthy individuals [91]. In further analysis, the same group determined the prevalence of enterovirus DNA and neutralising antibody in ME/CFS patients. Whereas enteroviral sequences in serum were found by PCR more frequently in the ME/CFS group (42\%) than in the control group (9\%), there were no statistical differences regarding coxsackievirus $B$ antibodies in the neutralisation tests (positive: ME/CFS 34\%, controls: 41\%) [92].

Gow et al. reported on the detection of enteroviral RNA in muscle biopsies from $53 \%$ of $60 \mathrm{ME} / \mathrm{CFS}$ in comparison to $15 \%$ of 41 controls [93]. Furthermore, quadriceps muscle biopsy samples from $20.8 \%$ of the 48 $\mathrm{ME} / \mathrm{CFS}$ patients were found to be positive for enterovirus sequences by reverse transcription (RT)-PCR, while all 29 control samples were negative [94]. In a study by Bowles et al. [95], molecular hybridization detected enteroviral RNA in muscle biopsies from 41 of 148 patients with ME/CFS, 25 of 96 patients with inflammatory muscle disease, and only two of 152 controls. In an earlier study, the same group had postulated that the enteroviral persistence in the muscle might be caused by a defect in the control of viral RNA synthesis as they found approximately equal amounts of enteroviral positive and negative RNA strands, in contrast to lytic infections, in which positive RNA strands dominate [96]. They speculated that persistence of viral RNA without synthesis of viruses could contribute to muscle dysfunction. In 2003, detection of enteroviral RNA without production of viral proteins was reported by Douche-Aourik et al., whose analysis of muscle biopsy samples revealed virus RNA positive samples in $13 \%$ (4/30) of ME/CFS patients and none of the controls
[97]. Enteroviral VP-1 protein could not be stained by immunohistochemistry in any of the samples.

In 2008, Chia et al. found that 135/165 (82\%) antrum biopsy specimens stained positive for enterovirus VP1 within parietal cells, whereas significantly fewer controls were stained positive $(7 / 34,20 \%)$ [98]. Enterovirus RNA was detected in 9/24 (37\%) paraffin embedded biopsy samples, and only $1 / 21$ controls had detectable enterovirus RNA. One out of 3 patients had detectable enterovirus RNA from two follow-up samples taken 4 years apart, whereas 5 patient samples showed transient growth of non-cytopathic enteroviruses [98]. In another study from the same group, 3 patients with acute enteroviral infection developed symptoms of ME/CFS during follow-up. Enteroviral persistence was demonstrated by detection of enteroviral RNA sequences in gastric biopsy specimens and in peripheral blood leukocytes (PBL) by qualitative RT-PCR [99]. It was also shown by Galbraith et al. that enteroviruses, $19 / 20$ of which were substantially different from previously described enteroviruses, can establish persistent infection, and in some cases, they can lead to the manifestation of ME/CFS [100]. In the group of patients who had been referred for assessment of fatigue, 44/238 serum samples and 29/175 throat swab samples were positive by enteroviral PCR assay, while sera from 3/130 healthy individuals were positive using the enteroviral PCR assay [100]. In a following study, eight individuals with ME/CFS were positive for enteroviral sequences, which were detected by PCR in two serum samples taken at least 5 months apart [101]. In addition, serological evidence has indicated that enteroviral activity may contribute to ME/CFS; increased titers of antibodies against coxsackieviruses B1 and B4 have been found among patients [74], and in a separate group, enterovirus IgG class antibodies were present in $49 \%$ of ME/ CFS patients. Within this cohort, acute infections were observed in $5 \%$ of patients [80]. The results of antiviral treatment provided additional arguments in support of a potential role for enteroviruses in the pathogenesis of $\mathrm{ME} / \mathrm{CFS}$, as 7 out of $10 \mathrm{ME} / \mathrm{CFS}$ patients with persistent enterovirus infection were successfully treated with alpha interferon and ribavirin or a combination of alpha and gamma interferon [102].

A study focussing on the analysis of immune activation in ME/CFS found a significantly higher prevalence of coxsackievirus infection in $63 \mathrm{ME} / \mathrm{CFS}$ patients (90\%) in comparison to 40 controls (65\%). However, geometric mean antibody IgG titers were similar in both groups [76]. In contrast, another study found elevated IgGtiters against coxsackievirus in only $6 \%$ of 107 ME/CFS patients, arguing against a major role of active coxsackievirus infection in ME/CFS, at least in that cohort. 


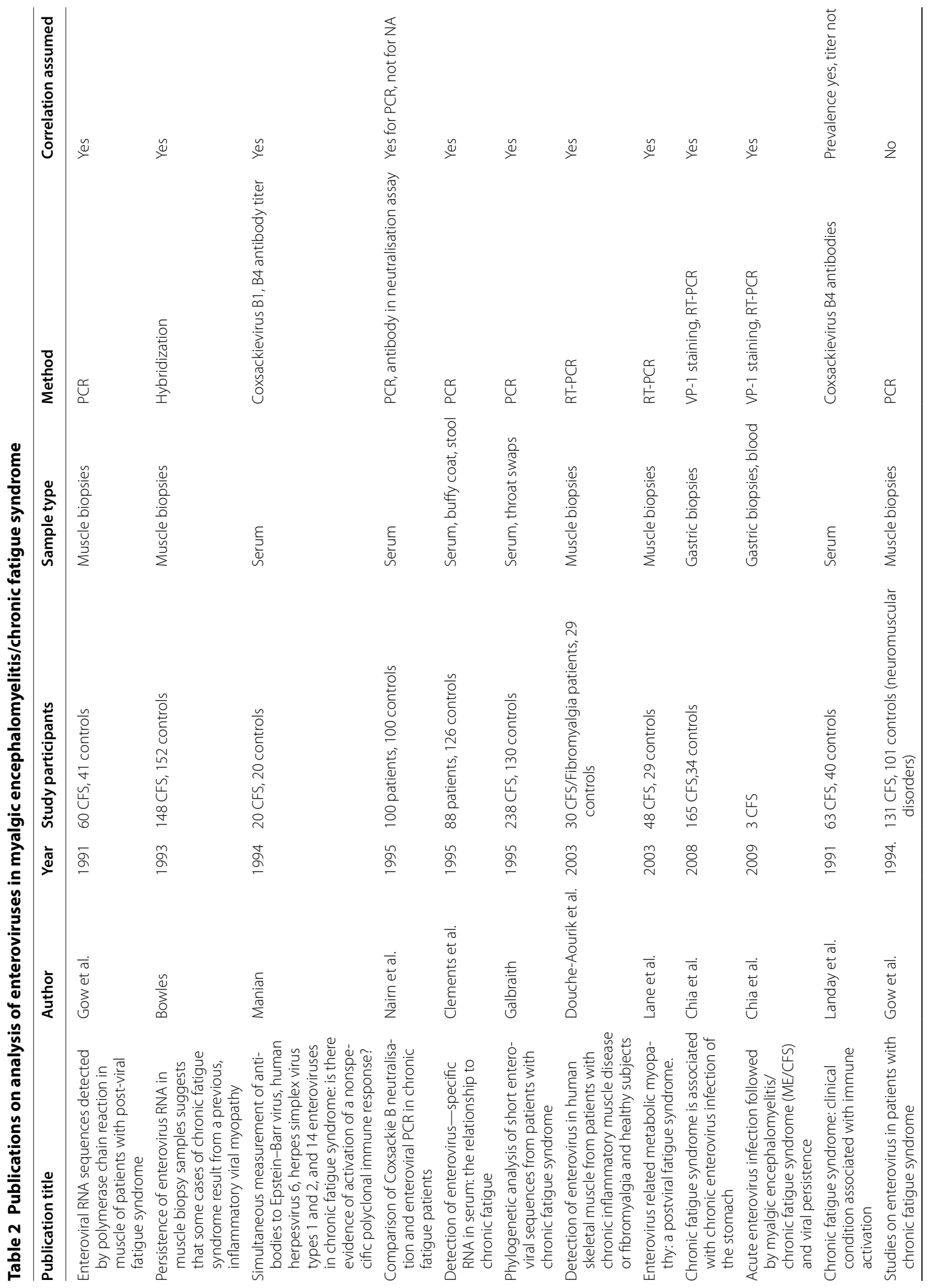




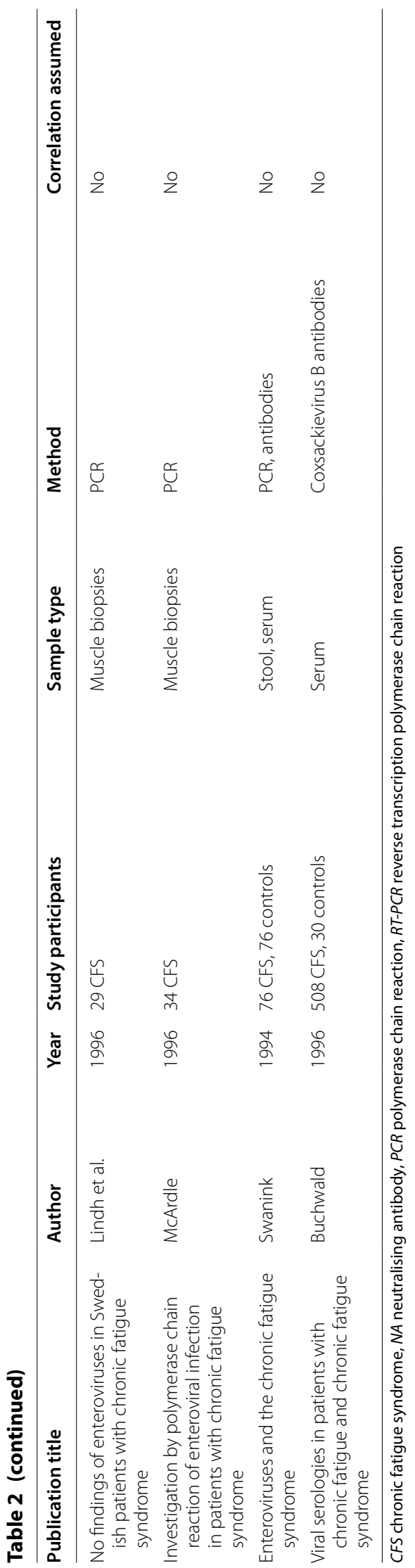


Other studies were not able to detect enterovirus infection in ME/CFS patients' blood, stool, serum, cerebrospinal fluid (CSF) and muscle biopsy samples [76, 81, 103-105]. In addition, there were no significant differences in the rates of detection of enteroviral RNA in muscle biopsies from a group of patients with ME/CFS (26.4\%), compared with a group of patients with other neuromuscular disorders (19.8\%). It was concluded that persistent enterovirus infection is unlikely to play a pathogenic role in ME/CFS, although an effect in initiating the disease process cannot be excluded [106].

\section{Human parvovirus B19}

$\mathrm{B} 19 \mathrm{~V}$ is an immunomodulating single-stranded DNA virus belonging to the Parvoviridae family, the Parvovirinae subfamily, and the Erythrovirus genus. It was discovered in 1975 in the serum of an apparently healthy donor [107].

B19V was first associated with a human disease in 1981 [108]. It is frequently detected in children, and consequently, $60-80 \%$ of adults have antibodies against this virus. It can cause rash, Erythema infectiosum or the fifth disease, arthralgia, various skin lesions, neutropenia, liver and lung disorders, papular-purpuric gloves and socks syndrome, hepato-biliary diseases, cardiac syndromes, autoimmune and neurological diseases, transient aplastic crisis with a short life-span and aplasia of red blood cells that is observed in immunocompromised patients [109, 110]. Viral DNA is eliminated from the serum within 4-5 months, and antibodies rapidly decrease. Many years after the primary infection and acute phase, B19V can persist in an organism, and persistent B19V infection has been investigated as a possible etiological agent in cases of encephalitis, encephalopathy, arthritis, autoimmune processes, fatigue and ME/CFS [111, 112].

Initial studies using PCR to examine the presence of B19V DNA in serum and bone marrow aspirates did not find evidence of involvement of B19V infection in bone marrow dysfunction in any of seven ME/CFS patients. Out of these 7 patients, only 1 patient had B19V specific antibodies [113]. Additionally, an analysis of 22 monozygotic twins revealed the presence of $\mathrm{B} 19 \mathrm{~V}$ genomic sequences in only one of the healthy twins as detected by PCR [61].

A link between B19V infection and subsequent onset of ME/CFS (1-3 years post-infection) has been published [114]. The results from this analysis revealed a significant association between the development of ME/CFS and high stress levels, as determined through the use of questionnaires, during acute B19V infection. Later, B19V DNA was found in plasma samples from 3/58 ME/ CFS patients and 2/49 healthy controls, while IgG class antibodies were observed in $52 \%$ and $57 \%$ of patients and controls, respectively, and IgM class antibodies not present at all [115]. Due to the detection of B19V DNA in gastro-intestinal biopsies from $40 \%$ of patients and fewer than $15 \%$ of controls, some researchers have concluded that, at least in a subset of patients, B19V could be involved in the pathogenesis of ME/CFS [68].

While analysing the presence of B19V infection markers in the serum of $200 \mathrm{ME} / \mathrm{CFS}$ patients and 200 healthy blood donors using real-time PCR, B19V DNA was detected in 11 patients with ME/CFS but in none of the healthy blood donors. A significant difference was not revealed in $\mathrm{B} 19 \mathrm{~V}$ seroprevalence (the proportion of individuals with anti-B19 VP2 IgG class antibodies) between patients with ME/CFS, $75 \%$ of whom were seropositive, and donors, who had a total seroprevalence of $78 \%$. Meanwhile, anti-B19V VP2 IgM class antibodies were found in 4 patients. In addition, $41.5 \%$ of patients and only $7 \%$ of donors had IgG class antibodies against nonstructural (NS1) protein, whereas B19V specific NS1 IgM class antibodies were found in 3 patients and one donor. The presence of B19V specific NS1 antibodies indicates a severe and persistent or chronic B19V infection; in this study, $73 \%$ of those with anti-NS1 antibodies suffered from joint pain, and positivity for these antibodies in ME/CFS patients was associated with greater expression of the human ME/CFS-associated genes NHLH1 and GABPA [116]. Another report described finding antiVP2 IgG class antibodies in 74\% of the analysed patients with ME/CFS and IgM in 1 patient. As was the case in the aforementioned study by Kerr et al., B19V seroprevalence among ME/CFS patients was shown to be similar to the percentage in the general population [80]. More recently, B19V VP2 specific antibodies were detected in plasma samples from $85 \%$ of the ME/CFS patients and $61 \%$ of practically healthy individuals [62]. Moreover, active B19V infection was detected in $28 \%$ of ME/CFS patients compared to $2 \%$ of controls using nested PCR, and active infection was linked to an increased frequency of joint pain [62]. In spite of these studies, there is no consensus on $\mathrm{B} 19 \mathrm{~V}$ as a causative agent of ME/CFS.

\section{Retroviruses}

Xenotropic murine leukemia related virus (XMRV) belongs to the Retroviridae family, Orthoretrovirinae subfamily and Gammaretrovirus genus, which was identified in 2006 while studying the lack of ribonuclease L coding antiviral gene RNASEL function in patients with prostate cancer [117]. The genome has $95 \%$ homology with several endogenous murine retroviruses and 94\% homology with exogenous murine retroviruses [10]. However, Paprotka et al. concluded that XMRV is probably a recombinant virus, which was generated by the recombination of two murine retroviruses (pre-XMRV1 and pre-XMRV-2) 
during passaging of prostate cancer cell lines in nude mice within a time period ranging from 1993 to 1996 [118].

XMRV was discovered in patients with prostate cancer, and publications reported potential associations between the virus and other diseases. The observations of RNase $\mathrm{L}$ proteolysis in PBMC from patients with ME/CFS and infectious-like chronic immune system activation led to examination of XMRV in these patients $[119,120]$. The XMRV gag gene sequence was detected by nested PCR in PBMCs of $67 \%$ out of 100 patients PBMCs but only in $3.7 \%$ out of 218 healthy donors PBMCs, and further analysis revealed $99 \%$ sequence identity with XMRV by sequencing viral genomes from 3 patients [120]. However, Science retracted this article in 2011, citing poor quality control in the experiments, the omission of important information regarding treatment of the ME/ CFS-patient PBMCs, and scepticism of the validity of the study [121].

In 2010, Lo et al. reported on the detection of MLVrelated virus gag gene sequences in $86.5 \%$ out of 37 patients and $6.8 \%$ out of 44 control group individuals [122]. However, in 2012, the authors retracted the publication. Later, many researchers published their efforts to detect XMRV in patients with ME/CFS and donors using serological and molecular methods. No evidence linking XMRV to ME/CFS was found in studies carried out in Germany, China, Sweden, the United Kingdom, Japan, the United States of America, Canada, the Netherlands, Latvia and Italy [123-135]. The presence of XMRV or MLV-related sequences, antibodies, or infectious virus was not confirmed in large ME/CFS patient groups, including a subset of the patients previously reported to be XMRV-positive by Lombardi and colleagues [136].

It has been suggested that the earlier positive findings were based on laboratory contamination [136-140]. Studies have shown that commercial reagents and clinical samples could be contaminated with MLV-related virus genomic sequences containing murine DNA, and cloned or amplified XMRV DNA might be the source of contamination. It could also originate from frequently used XMRV-infected prostate cancer cell line 22Rv1 [141]. Various geographic localizations may explain differences in some results, but not in the same country. Another reason for problems with XMRV detection was thought to be XMRV sequence variation or the presence of XMRV-like viruses. XMRV strain identity is 99\%; therefore, the existence of distinct or related viruses is possible, and detection of them with PCR or some other methods can be difficult [10]. After several years of studies, large effort and expenses from clinicians, scientists and patients, it was concluded that there is no association between XMRV and human diseases, and positive results were consequences of contamination [142].

Studies on several other retroviruses (HTLV-I and -II, HIV-1/2, spuma viruses) in ME/CFS were performed. Whereas DeFreitas reported on the presence of antibodies to HTLV-II and retroviral sequences in blood cells in patients with ME/CFS, these findings could not be reproduced by other groups [76, 143, 144]. Therefore, the theory of retroviral etiology in ME/CFS is not currently supported.

\section{Ross River virus}

Another post-viral fatigue-causing virus is a singlestranded positive-sense RNA virus-Ross River virus (RRV), which belongs to the family Togaviridae, genus Alphavirus. Mosquitoes transmit this viral infection from infected animals to humans, and symptoms of the infection overlap with the symptoms of ME/CFS. Back in 1996, Selden and Cameron published a study in which such symptoms as joint pain, persistent tiredness, lethargy, myalgia, lymphadenopathy, headache, and depression were observed even 30 months after infection with RRV in South Australia [145].

Using an antibody-dependent enhancement mechanism, RRV has been found to infect macrophages and enable suppression of specific antiviral genes expressed by these cells, which results in unimpeded replication [146]. An additional study by these two authors showed suppression of functional activity of STAT1 and NF- $\mathrm{KB}$ transcription factor protein complexes due to antibodydependent enhancement of RRV infection [147].

Later, acute RRV or EBV infection followed by fever, malaise, pain, fatigue, and mood and concentration disorders were correlated with elevated levels of pro-inflammatory cytokines [148]. Analysing the same patient cohort in Australia, Hickie and colleagues studied the prevalence and course of post-infectious fatigue and chronic fatigue following acute RRV, EBV and Coxiella burnetii infection, demonstrating that severity of acute viral infection and the host response to it may determine the course of post-infectious syndrome and ME/CFS [82]. More recent attempts to find a possible illness-specific signature of peripheral blood gene expression in patients with post-infectious fatigue caused by RRV, EBV, or Coxiella burnetii, was not successful [149]. Subsequently, this team hypothesized that inflammatory cytokines influence the CNS, resulting in neurocognitive disturbances following acute infection, and therefore, certain infectious agent may not determine symptoms. Moreover, genetic predisposition of specific cytokine expression has been found to affect cognitive manifestations, particularly during acute infection [150]. 


\section{Molecular mechanisms behind viral pathogenesis} in ME/CFS

Viral infection can initiate a multitude of physiological changes in host cells that can contribute to ME/ CFS development (Fig. 1). Viral pathogens frequently associated with ME/CFS are also known to alter various molecular processes in host cells that define clinical conditions of ME/CFS (Table 3). Three of the most frequently discussed molecular processes, namely immune cell alterations, mitochondrial modulation and autoimmunity, are described in brief within this section.

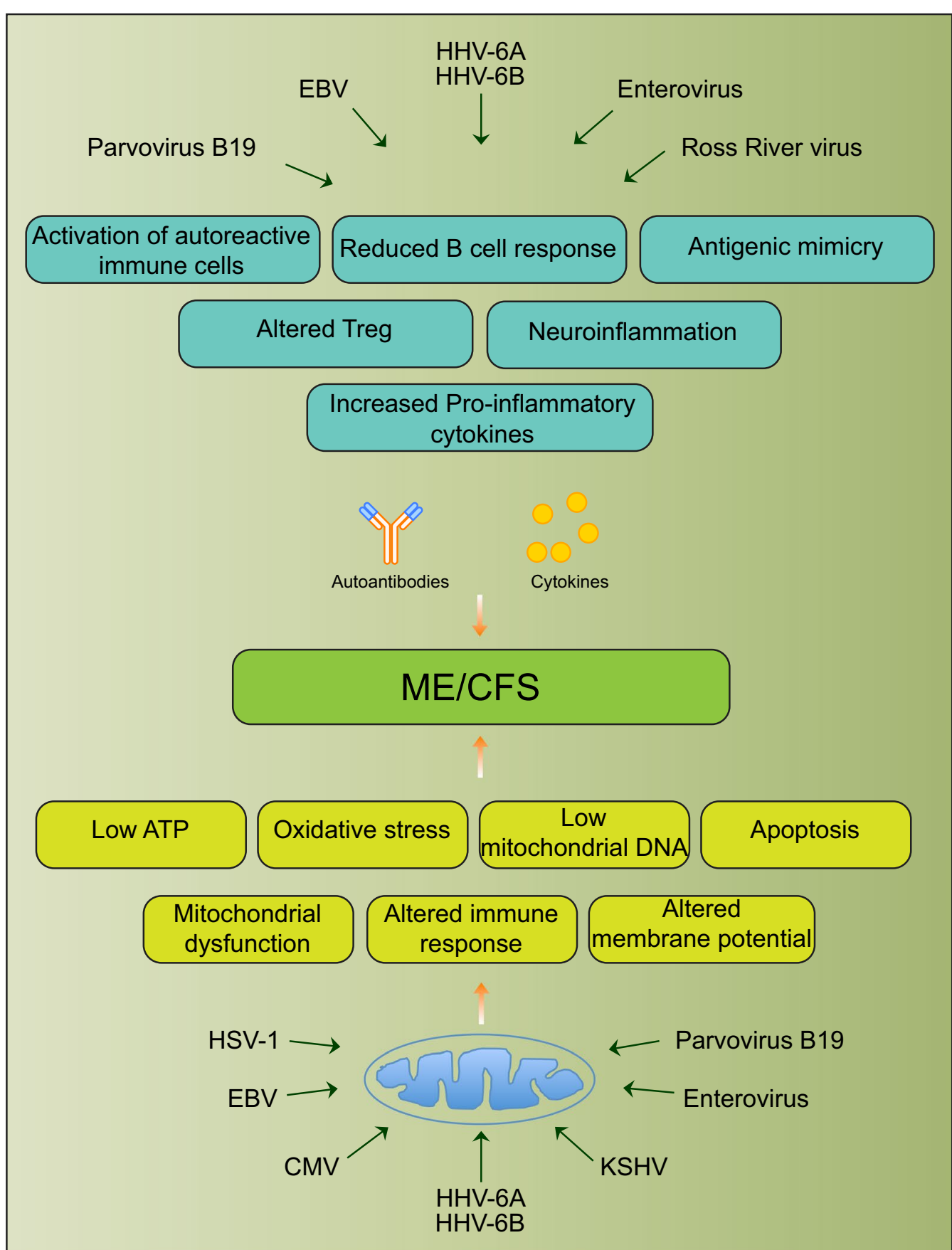

Fig. 1 Schematic diagram showing various viral pathogens potentially associated with ME/CFS and possible molecular mechanisms altered by these pathogens that can contribute to ME/CFS development 
Table 3 Possible viral contributions towards ME/CFS

\begin{tabular}{|c|c|}
\hline Viruses & Contribution in ME/CFS \\
\hline Human herpesviruses & $\begin{array}{l}\text { Persist after primary infection in latent phase and can reactivate causing lytic virus replication } \\
\text { Infected cells are recognized by immune system resulting in chronic inflammation that causes ME/CFS symptoms } \\
\text { Disturb first class major histocompatibility complex (MHC) molecules presenting virus antigen } \\
\text { Alter NK, T and B cell function } \\
\text { Modify expression of cellular transcripts } \\
\text { Trigger immune dysregulation } \\
\text { Alter cytokine production resulting in appearance of ME/CFS typical symptoms } \\
\text { Contribute in affecting signalling pathways to proper immune response } \\
\text { Activate humoral immune response by herpesviruses-encoded dUTPases } \\
\text { Infect neurons and immune cells to impair CNS capillaries and micro-arteries, leading to brain damage } \\
\text { Produce a pro-inflammatory environment and autoimmune activity } \\
\text { Damage tissue, leads to inflammation and may activate auto-reactive T and B cells, thereby contributing to autoimmunity } \\
\text { Local virus-associated inflammation of nervous structures results in altered CNS and PNS signalling } \\
\text { Alter ATP homeostasis, increase ROS, change mitochondrial metabolism and modulate mitochondrial DNA content }\end{array}$ \\
\hline Enteroviruses & $\begin{array}{l}\text { Infect various tissue (blood, gastric, muscle, brain) and stool } \\
\text { Persistence of viral RNA could contribute to muscle dysfunction } \\
\text { Induce tissue damage } \\
\text { Dysregulate host microRNAs } \\
\text { Induce greater oxidative stress, inflammation, and pro-inflammatory M1 macrophage activity } \\
\text { Induced inflammation can result in bystander activation of auto-reactive cells } \\
\text { Coxsackie B4 virus infects beta cells leading to NK cell induced non-destructive inflammation } \\
\text { Severe acute enterovirus } 71 \text { infection diminishes number of NK and T cells and induces ROS accumulation }\end{array}$ \\
\hline Parvovirus B19 & $\begin{array}{l}\text { After primary infection and acute phase can establish persistent infection and lead to the manifestation of ME/CFS } \\
\text { Interacts directly with cells leading to a more aggressive fibroblast function and degradation of cartilage matrix } \\
\text { Active infection is linked to an increased frequency of joint pain } \\
\text { VP1 protein affects arachidonic acid metabolism promoting inflammatory reactions } \\
\text { NS1 protein stimulates pro-inflammatory cytokines production causing local inflammation } \\
\text { Activates NK cells } \\
\text { Causes neuroinflammation } \\
\text { Contributes to greater expression of the human CFS-associated genes NHLH1 and GABPA } \\
\text { May induce autoimmunity }\end{array}$ \\
\hline Retroviruses & No contribution \\
\hline Ross-River virus & $\begin{array}{l}\text { Infect macrophages using antibody-dependent enhancement mechanism } \\
\text { Suppresses transcription and translation of antiviral genes } \\
\text { Generate neurocognitive manifestations affected by functional polymorphisms in cytokine genes } \\
\text { Cause joint pain, persistent tiredness, lethargy, myalgia, lymphadenopathy, headache and depression }\end{array}$ \\
\hline
\end{tabular}

\section{Virus-induced alterations to immune cells}

One commonality among the viruses linked to ME/ CFS appears to be the ability to establish persistent infections. In order to do that, viruses must bypass and evade immune cells, and in doing so may alter immune cell functions. While several viruses may contribute to ME/CFS, the immunomodulatory capacity of the viral species, perhaps paired with its ability to establish persistent infection, may underlie its pathological potential in the setting of ME/CFS. Elevated activity of antiviral enzyme $2^{\prime}-5^{\prime}$-oligoadenylate synthetase (OAS) in PBMC from patients with ME/CFS has been observed. This protein is induced by IFN- $\alpha$ and IFN- $\beta$, and degrades viral RNA and inhibits virus replication. Therefore, it plays an important role in the response against viral infections. The level of OAS correlates with severity of ME/CFS, suggesting that a chronic virus infection could be the cause of ME/CFS [151]. Moreover, proof of humoral immune response activation by herpesviruses-encoded dUTPases in patients with ME/ CFS has been published [85].

The establishment of a persistent infection is influenced by immunosuppression and activated immune complexes, which may cause chronic inflammation $[15,152$, 153]. Chronic immune system activation is accompanied by alterations in regulation of cytokine production [154], and stimulated lymphoid cells express or induce the expression of various cytokines in other cells that can set the stage for pathological manifestations [155]. Low-level inflammation and activation of cell-mediated immunity is observed in ME/CFS cases and the high level of TNF- $\alpha$ correlates with several clinical symptoms; therefore, an increase of inflammatory mediators might explain symptoms of the disease [156]. Likewise, it is possible that a viral infection causes dysfunction in cellular immunity, which consequently induces viral reactivation. Subsequently, viral proteins facilitate cytokine secretion, resulting in appearance of typical ME/CFS symptoms, 
such as fatigue, fever, sleep and cognitive disorders [7]. Chronic pain may be caused by inflammatory signals that are spread by glial cells activated by inflammatory cytokines and neuronal stimulation [153, 157].

In establishing persistence, viruses may induce immune disturbances directly and indirectly; for instance, they may infect cells involved in mediation of cellular and humoral immune response, and through indirect interactions, they might alter cell surface receptor expression as well as cytokine and chemokine expression levels, leading to local inflammation [158]. Infection of cells by enteroviruses affects cellular miRNA expression, which may result in dysregulation of immune pathways and cytokine production, and these viruses can reduce expression of type I and III interferon, which are primarily produced by natural killer (NK) and T cells [159-161]. Herpesviruses like HHV-6 are also able to alter expression of cellular miRNAs in various cell types including NK cells $[162$, 163], as well as cellular expression of NK cell receptors [164], and they may express their own miRNAs that aid in immune evasion [165]. Downregulated cytotoxic activity of NK cells in ME/CFS could be linked to a decreased expression level of NK cell activating receptor NKG2D [166], the ligand of which is down-regulated by HHV6B [164]. In addition, the expression of viral homologs of cytokines/chemokines and cytokine/chemokine receptors by herpesviruses can impact immune pathways [167, 168]. Other herpesvirus-induced alterations to ligand/ receptor signalling between NK and associated cells could also contribute to the pathogenic mechanism of the viruses in ME/CFS are described [169].

Enteroviruses, as well as most of the herpesviruses, use mechanisms that disturb first class major histocompatibility complex (MHC) molecules presenting virus antigen $[167,170,171]$. The HHV-7 U21 gene product interrupts viral antigen presentation to cytotoxic $\mathrm{T}$ cells that causes $\mathrm{MHC}$ class I molecules degradation in lysosomes. Besides interfering with the host cytotoxic $\mathrm{T}$ cell response, U21 lessens NK cell cytotoxicity [172]. Such changes of immunological parameters as a decreased count of $\mathrm{CD}^{+}$ and $\mathrm{CD} 4^{+} \mathrm{T}$ cells, an increase of $\mathrm{CD} 95^{+}$and a decrease of $\mathrm{CD} 4^{+} / \mathrm{CD}^{+}{ }^{+}$ratio are observed in patients with a concurrent active HHV-6 and HHV-7 infection [64]. Other studies also show $\mathrm{CD}^{+}{ }^{+} \mathrm{T}$ cell response to HHV-6 [173].

In vitro studies show that a possible mechanism of action for $\mathrm{B} 19 \mathrm{~V}$ is direct virus interaction with cells leading to more aggressive fibroblast functionality and degradation of cartilage matrix. Moreover, the activity of capsid protein VP1 affects arachidonic acid metabolism promoting inflammatory reactions, and the B19V non-structural NS1 protein also stimulates pro-inflammatory cytokine production, causing local inflammation [174] that might account for such ME/CFS clinical manifestations as fatigue, lymphadenopathy, joint pain, and muscle pain $[68,175,176]$. Enteroviruses $[177,178]$ and herpesviruses may also contribute to these signs and symptoms through up-regulation of pro-inflammatory cytokines [179].

Some viruses, like RRV, are able to infect macrophages using an antibody-dependent enhancement mechanism, suppressing antiviral genes and thereby resulting in replication [146]. The antiviral response to RRV is diminished by suppression of transcription factor protein complex activity [147]. In the case of acute RRV infection, functional polymorphisms in cytokine genes may affect the influence of inflammatory cytokines in the CNS and resulting neurocognitive manifestations [150].

\section{Viruses and mitochondrial modulation}

ME/CFS is considered to be a mitochondrial disease [180]. Some of the characteristic features of ME/CFS involve altered adenosine triphosphate (ATP) homeostasis [181, 182], increased reactive oxygen species (ROS) [183], changed mitochondrial metabolism [184, 185], and modulation of mitochondrial DNA content [182, 186, 187]. Many of the aforementioned viruses modulate host mitochondria in a variety of ways that can potentially present plausible explanations regarding the involvement of these viruses in ME/CFS. Viruses have evolved distinctive strategies to alter mitochondrial metabolism and bioenergetics, which may allow enhanced viral replication and provide anti-viral defence.

HSV-1 infection decreases cellular ATP levels and mitochondrial membrane potential [188], and HSV-1 anti-apoptotic protein $\mathrm{gJ}$ has been shown to induce ROS formation [189]. In vitro experiments in mammalian cells have shown rapid and complete degradation of host mitochondrial DNA by HSV-1 [190]. Evidence of mitochondrial dysfunction has been associated with post-infective fatigue after EBV infection [191], and EBV is known to alter mitochondrial dynamics through direct interaction [192]; the immediate early protein of EBV, Zta, interacts with mitochondrial single stranded DNA binding protein, leading to reduced mitochondrial DNA (mtDNA) replication and enhanced viral DNA replication [193]. HHV-6B improves viral infection through direct interaction of its U95 protein with human GRIM-19 protein [194], and the virus increases oxidative stress during persistent infection by reducing glutathione reductase activity [195]. During productive infection, HHV-6A can cause apoptosis through a caspase-dependent pathway accompanied by altered mitochondrial morphology and lower transmembrane potential $[163,196]$. Similarly, latent $\mathrm{CMV}$ has been associated with greater oxidative damage [197]. HHV-8 modulates mitochondrial antiviral signalling via its interferon regulatory factor 1 [198]. 
In addition, porcine and canine parvovirus infection induces depolarization of the mitochondrial membrane, damage to the organelle's structure [199], and ROS accumulation [200, 201]. Enterovirus 71 also induces ROS accumulation [202] for its successful replication.

\section{Viruses and autoimmune signature}

Autoimmune signature in ME/CFS has recently become a subject of intense research [29, 203]. Viral pathogens can contribute to autoimmune diseases in variety of ways. Because the viruses associated with ME/CFS are also commonly detected among healthy individuals, it may be the case that underlying immune dysfunction in the host acts as a predisposing factor in development of the disorder. Viruses may trigger immune dysregulation, but an individual may also be predisposed to either an exceptionally strong acute infection, an inability to completely clear the virus, or both. Subsequently, the abnormal immune profile post-acute infection may allow for continuous reactivation and incomplete clearance of pathogens, resulting in tissue damage and an overactive yet ineffective immune response leading to inflammation and autoimmune changes. The absence of strong viremia indicates that the viruses that are present are likely quite tissue-specific, and data suggests that the viral activity consists of greater "latency-associated replication", as was noted for EBV [72]. The success of valganciclovir (active against CMV and HHV-6) and valacyclovir (active against HSV, VZV, and EBV) $[86,204]$ as well as rituximab and immunoadsorption of $B 2$ autoantibodies in subsets of ME/CFS patients suggests that both the viral activity itself and the immune response against/resulting from viral infection may contribute to the signs and symptoms of the illness [205, 206].

Enteroviruses, particularly B coxsackieviruses, are implicated in type 1 diabetes mellitus, which they may contribute to through dysregulation of host microRNAs [207] and induction of greater oxidative stress, inflammation, and proinflammatory M1 macrophage activity [208]. Chronic enterovirus-associated systemic or local inflammation, as a consequence of a weak innate immune response and virus-induced tissue damage, may result in bystander activation of auto-reactive cells. On the other end of the spectrum, an overactive innate immune response may also result in inflammation during the initial acute infection, leading to the same outcome [209]. This scenario has been proposed for enteroviruses in type 1 diabetes, but the theory may be more broadly applicable to other viruses and autoimmune conditions. Activation of auto-reactive bystander cells has also been proposed as a pathogenic factor in systemic lupus erythematosus [210], as has molecular mimicry.
The viruses discussed herein are capable of activating $\mathrm{NK}, \mathrm{B}$, and $\mathrm{T}$ cells, modifying expression of their cellular transcripts, altering cytokine production, and affecting signalling pathways integral to the proper functioning of the immune response, potentially producing a proinflammatory environment and autoimmune activity. For example, NK cells induce non-destructive inflammation in response to beta cell infection by coxsackie B4 enterovirus [211] and are activated by acute B19V infection [212], but NK and T cells are diminished in number during severe acute infection of enterovirus 71 [213]. HHV-6A-infected T cells express many miRNAs associated with inflammation and autoimmunity [214], and persistent HHV-6A infection is associated with altered NK cell profiles in cases of Hashimoto's thyroiditis and acute necrotizing encephalopathy. These infections were characterized by incomplete clearance of the virus and a greater abundance of peripheral CD56bright NK cells $[215,216]$. This environment of heightened cytokine secretion paired with the ineffectual clearance of infection may activate auto-reactive $\mathrm{T}$ and $\mathrm{B}$ cells, thereby contributing to autoimmunity. Indeed, the cellular activation of the CD56bright NK cells correlated with autoantibody levels in subjects with Hashimoto's thyroiditis.

Interactions between the viruses and innate and adaptive immune cells are dynamic and vary temporally, across viral species, and between individual patients. Accordingly, activity of these cells has been found to vary across studies of ME/CFS and even within studies, according to the time-point [217]. Although cytokine expression and immune cell phenotypes have differed [62, 218], dysregulation of immune cell networks occurs in ME/CFS patients, and a pro-inflammatory milieu appears to predominate. Additionally, it is clear that patients' immune responses against viruses differ from unaffected individuals. While healthy volunteers did not exhibit changes in cellular proliferation after vaccination with influenza strains, for example, ME/CFS patients displayed significantly higher cellular proliferation in response to stimulation compared to baseline [219]. Baseline $\mathrm{T}$ cell proliferation was lower than controls, and post-vaccination proliferation was higher in $\mathrm{ME} /$ CFS patients compared to controls, although these findings were not statistically significant. Lower proliferative responses were observed among other ME/CFS patients as well [220], and decreased cytotoxicity of NK and T cells [217], as well as increased levels of cytokine producing CD56bright NK cells [221], have been documented, although findings have not been consistently confirmed between studies.

Failure to produce IgG antibodies against EBV EBNA-1 has been noted, as has low levels of antibody secreting cells specific to EBNA-1 and VCA and an impaired 
B cell memory response to the virus [72]. Responses of EBV-specific B- and T-cells were suppressed, which has been suggested to result from frequently reactivated EBV and lymphocytic exhaustion. In contrast, reduced CMV and HSV specific B-cell responses were not identified. On the other hand, the presence of antibodies against EBV DNA polymerase and EBV-encoded dUTPase has been detected in the serum of a subset of ME/CFS patients but not in controls [84], and the IgG response to EBV EBNA-6 peptides has been heightened in ME/CFS [73]. Sequences of amino acids in the EBNA-6 repeat region were found to be homologous to the human lactoperoxidase precursor (LPO) and thyroid peroxidase precursor (TPO) proteins as well as the two enzymes ornithine transcarbamylase (OTC) and phosphofructokinase-1 (PFK-1), which have metabolic functions. Of these, only LPO peptide IgG levels correlated with EBNA-6 peptide and protein IgG. However, antigenic mimicry producing cross-reactivity among these proteins is considered as a possible factor behind ME/CFS pathogenesis. Analysis of genetic associations has revealed that the EBV protein EBNA-2 and its related human transcription factors are associated with many autoimmune risk loci, including those involved in MS, rheumatoid arthritis, type 1 diabetes, and systemic lupus erythematosus [222]. NF-kB was similarly associated.

Although systemic immune dysfunction has been observed, local virus-associated inflammation of nervous structures resulting in altered CNS and peripheral nervous system signalling has also been hypothesized as a mechanism behind ME/CFS [223, 224], and neuroinflammation has been observed in patients [225]. EBV [226], HSV [227], HHV-6 [228], CMV [229], VZV [230], enterovirus [231], and B19V [232] can all infect the brain. Notably, HHV-6A is able to induce neuroinflammation in the absence of active replication in a mouse model [233]. HHV-6A has also been found to impair myelin repair in vitro and in vivo using mouse with extensive loss of myelin [234].

HHV-6 has been strongly linked to autoimmune diseases like Hasimoto's thyroiditis [235, 236], connective tissue disorders and MS [237]. Selective reactivation of HHV-6 has also been shown in patients with autoimmune connective tissue diseases [238]. MS patients are frequently detected with high levels of HHV-6A/B-specific IgG and IgM in the serum and CSF [239]. Myelin basic protein (MBP), one of the auto-antigens implicated in MS pathology shares amino acid sequence homology with the U24 protein from HHV-6 [240]. Hence molecular mimicry is considered as one of the potential mechanisms for HHV-6 mediated autoimmune diseases. Clinical cases showing increased glutamic acid decarboxylase (GAD) antibodies and HHV-6 infection has been reported where antiviral therapy improved patient's clinical condition [241].

HHV-6B has weaker ties to autoimmunity, but it is thought to contribute to common symptoms of severe drug-induced hypersensitivity syndrome/drug reaction with eosinophilia and systemic symptoms (DIHS/ DRESS) when it reactivates strongly during the course of the syndrome. The immune response to the viral activity is considered as potentially more destructive than the viral activity itself and is implicated in visceral organ damage [242]. Notably, initial regulatory $T$ cell (Treg) expansion in this illness contrasts with subsequent exhaustion of Treg cells during remission, which appears to set the stage for the autoimmune sequelae that commonly occur afterward [243]. Autoimmune thyroiditis and diabetes mellitus frequently arise postDIHS/DRESS, as does chronic fatigue. HHV-6 has been detected in Treg cells in a case of likely DIHS/ DRESS [244], and HHV-6A [245] and HHV-6B [246] are also able to induce the development of Treg cells. Both upregulated and reduced levels of Tregs have been reported in ME/CFS [217, 221, 247].

The molecular link between B19V infection and autoimmune disorders is not very clear. However, B19V infection has been associated with development of autoimmune antibodies including rheumatoid factor [110, 248, 249], antinuclear antibody, anti-mitochondrial antibody, smooth muscle antibody, and gastric parietal cell antibody [250]. Recently, B19V infection has been shown to increase levels of cytokines like IL-4, IL-10, IL-12, IL-2 and TNF $\alpha$ in the plasma of rheumatoid arthritis patients [251]. B19V induced upregulation of IL-6 has also been noted for its potential role in autoimmunity [252]. Two of the B19V proteins, a proline-rich small protein [253] and the NS1 protein [254], which also function as a transcription regulator have been intensely studied because of their role in viral pathogenesis. These proteins also contribute to host cell immune modulation through their involvement in cell survival pathways [254, 255]. B19V has been implicated in clinical cases of systemic lupus erythematosus and rheumatoid arthritis where various auto-antibodies could be detected in patients. Intravenous immunoglobulin (IVIG) has been reported to reduce symptoms in some patients with persistent B19V infection, but IVIG administration has also resulted in unexpected worsening of symptoms in a ME/CFS patient [256]. This may indicate that, in some cases, the immune response against persistent infection contributes to the development of clinical symptoms more so than infection-induced tissue damage, and IVIG may contribute to increased inflammation. Heightened viral replication was also detected in this case, which was suggested to be a result of antibody-dependent enhancement. 
At least in a subset of patients, the mitochondrial dysfunction and elements of autoimmunity that characterize ME/CFS may be linked to viral pathogenesis. Lack of extensive analysis of molecular mechanisms linking viral pathogens to ME/CFS restricts our understanding of this disease. Future studies need to focus on this aspect of ME/CFS research.

\section{Conclusions}

Currently available data on the role of chronic viral infection with ME/CFS is still controversial, showing potential viral involvement for at least a subgroup of ME/CFS patients. Therefore, it is necessary to assess the presence and markers of viral activity at the initial stage of the disease to evaluate possible etiological factors and conduct longitudinal studies in order to assess active viral infection and symptom severity variations over time. Moreover, results should be compared not only between ME/ CFS patients and controls, but also with other co-morbidities to assess specificity of suggested biomarkers.

Considering ME/CFS heterogeneity, the use of clinical characteristics and biomarkers to enable definition of the disease subtypes is crucial. In addition, longitudinal and standardized studies determining ME/CFS course and therapy effectiveness with follow-up measurements in dynamics should be accomplished. This will allow prognosis of the disease development and promote development of a specific definition for diagnostics and a treatment plan.

\section{Future strategies for development of infection biomarkers in ME/CFS}

1. Use of quantitative assays rather than qualitative assays to assess the extent of the viral load instead of simple detection of presence or absence. This may facilitate monitoring of a response to treatment; however, diurnal variations and individual response on treatment should be taken into account. Further comprehensive serological testing may help to identify a signature of active infection.

2. Use of additional biological samples together with blood and serum will be useful in determining the localization and distribution of biomarkers, as well as pathogenicity. Using hair follicles, virus integration can be detected. Similarly throat swab and stool samples can be used for detection of enteroviruses.

3. Functional studies to compliment clinical biomarker studies in order to clarify functions and interactions of genes, transcripts, proteins, and immune cells and molecules in cases of ME/CFS. This will facilitate understanding of the disease aetiology as well as development and maintenance pathways, and thereby, potential prevention and treatment strategies. However, this strategy requires definition of ME/CFS subgroups.

4. Use of high throughput methods to gain broader insight into potential biomarkers for infections by obtaining and analysing large-scale data, which will raise the quality and significance of the research.

5. Confirmation of results by validation studies and multi-centre cohort studies to obtain generalizability of the study and promote implementation of credible biomarkers usable worldwide.

\section{Authors' contributions}

$\mathrm{BKP}, \mathrm{SR}, \mathrm{NH}$ conceived the idea and wrote the first draft of the manuscript; $\mathrm{ZN}, \mathrm{EE}, \mathrm{ES}, \mathrm{TH}, \mathrm{CS}, \mathrm{MM}$ contributed towards writing and final editing of the manuscript. All authors read and approved the final manuscript.

\section{Author details}

${ }_{1}^{1}$ Institute of Microbiology and Virology, Rīga Stradinš̌ University, Riga, Latvia. ${ }^{2}$ Biocenter, Chair of Microbiology, University of Würzburg, Würzburg, Germany. ${ }^{3}$ Institute for Virology and Immunobiology, Würzburg, Germany. ${ }^{4}$ Department of Virology, National Center of Infectious and Parasitic Diseases, Sofia, Bulgaria. ${ }^{5}$ Department of Internal Medicine 3, Universitätsklinikum Erlangen, FriedrichAlexander-University Erlangen-Nürnberg (FAU), Erlangen, Germany. ${ }^{6}$ Institute for Medical Immunology, Charité-Universitätsmedizin Berlin, Campus Virchow, Berlin, Germany.

\section{Acknowledgements}

We thank EUROMENE, a part of COST Action CA15111 under EU Framework Program Horizon 2020 for supporting the work.

\section{Competing interests}

The authors declare that they have no competing interests.

\section{Availability of data and materials}

Data sharing is not applicable to this article as no datasets were generated or analysed during the current study.

Consent for publication

Not applicable.

Ethics approval and consent to participate

Not applicable.

\section{Funding}

This review is based upon work from European Network on Myalgic Encephalomyelitis/Chronic Fatigue Syndrome (EUROMENE) as part of COST Action CA15111 supported by the EU Framework Program Horizon 2020 (Website: http://www.cost.eu/COST_Actions/ca/CA15111). Other funding sources- the Bulgarian National Science Fund [ДКОСТ 01/9 to E.S.], Solve ME/CFS Initiative, USA (to BKP).

\section{Publisher's Note}

Springer Nature remains neutral with regard to jurisdictional claims in published maps and institutional affiliations.

Received: 2 August 2018 Accepted: 24 September 2018

Published online: 01 October 2018

References

1. Brurberg KG, Fonhus MS, Larun L, Flottorp S, Malterud K. Case definitions for chronic fatigue syndrome/myalgic encephalomyelitis (CFS/ ME): a systematic review. BMJ Open. 2014;4:e003973. 
2. Underhill RA. Myalgic encephalomyelitis, chronic fatigue syndrome: an infectious disease. Med Hypotheses. 2015;85:765-73.

3. Carruthers M, Kumar Jain A, De Meirleir K, Peterson DL, Klimas NG. Myalgic encephalomyelitis/chronic fatigue syndrome: clinical working case definition, diagnostic and treatment protocols. J Chronic Fatigue Syndr. 2003;11:7-115.

4. Bested AC, Marshall LM. Review of myalgic encephalomyelitis/chronic fatigue syndrome: an evidence-based approach to diagnosis and management by clinicians. Rev Environ Health. 2015;30:223-49.

5. Lorusso L, Mikhaylova SV, Capelli E, Ferrari D, Ngonga GK, Ricevuti G. Immunological aspects of chronic fatigue syndrome. Autoimmun Rev. 2009;8:287-91.

6. Jason LA, Richman JA, Rademaker AW, Jordan KM, Plioplys AV, Taylor RR, McCready W, Huang CF, Plioplys S. A community-based study of chronic fatigue syndrome. Arch Intern Med. 1999;159:2129-37.

7. Bansal AS, Bradley AS, Bishop KN, Kiani-Alikhan S, Ford B. Chronic fatigue syndrome, the immune system and viral infection. Brain Behav Immun. 2012;26:24-31.

8. Johnston S, Brenu EW, Staines D, Marshall-Gradisnik S. The prevalence of chronic fatigue syndrome/myalgic encephalomyelitis: a meta-analysis. Clin Epidemiol. 2013;5:105-10.

9. Steele L, Dobbins JG, Fukuda K, Reyes M, Randall B, Koppelman M, Reeves WC. The epidemiology of chronic fatigue in San Francisco. Am J Med. 1998;105:83S-90S

10. Silverman RH, Nguyen C, Weight CJ, Klein EA. The human retrovirus XMRV in prostate cancer and chronic fatigue syndrome. Nat Rev Urol. 2010;7:392-402.

11. Fukuda K, Straus SE, Hickie I, Sharpe MC, Dobbins JG, Komaroff A. The chronic fatigue syndrome: a comprehensive approach to its definition and study. International Chronic Fatigue Syndrome Study Group. Ann Intern Med. 1994;121:953-9.

12. Carruthers BM, van de Sande MI, De Meirleir KL, Klimas NG, Broderick G, Mitchell T, Staines D, Powles AC, Speight N, Vallings R, et al. Myalgic encephalomyelitis: international consensus criteria. J Intern Med. 2011;270:327-38

13. Afari N, Buchwald D. Chronic fatigue syndrome: a review. Am J Psychiatry. 2003;160:221-36.

14. Prins JB, van der Meer JW, Bleijenberg G. Chronic fatigue syndrome. Lancet. 2006;367:346-55.

15. Krueger GR, Ablashi D. Human herpesvirus-6, second edition, general virology, epidemiology and clinical pathology. Perspectives in medical virology. Netherlands: Elseviere; 2006. p. 251-62.

16. Fluge O, Bruland O, Risa K, Storstein A, Kristoffersen EK, Sapkota D, Naess $\mathrm{H}$, Dahl O, Nyland H, Mella O. Benefit from B-lymphocyte depletion using the anti-CD20 antibody rituximab in chronic fatigue syndrome. A double-blind and placebo-controlled study. PLoS ONE. 2011;6:e26358.

17. Straus SE, Tosato G, Armstrong G, Lawley T, Preble OT, Henle W, Davey R, Pearson G, Epstein J, Brus I, et al. Persisting illness and fatigue in adults with evidence of Epstein-Barr virus infection. Ann Intern Med. 1985;102:7-16.

18. Holmes GP, Kaplan JE, Stewart JA, Hunt B, Pinsky PF, Schonberger LB. A cluster of patients with a chronic mononucleosis-like syndrome. Is Epstein-Barr virus the cause? JAMA. 1987;257:2297-302.

19. Martin WJ. Detection of RNA sequences in cultures of a stealth virus isolated from the cerebrospinal fluid of a health care worker with chronic fatigue syndrome. Case report. Pathobiology. 1997;65:57-60.

20. Buchwald D, Cheney PR, Peterson DL, Henry B, Wormsley SB, Geiger A, Ablashi DV, Salahuddin SZ, Saxinger C, Biddle R, et al. A chronic illness characterized by fatigue, neurologic and immunologic disorders, and active human herpesvirus type 6 infection. Ann Intern Med. 1992;116:103-13.

21. Yalcin S, Kuratsune H, Yamaguchi K, Kitani T, Yamanishi K. Prevalence of human herpesvirus 6 variants $A$ and $B$ in patients with chronic fatigue syndrome. Microbiol Immunol. 1994;38:587-90.

22. Ablashi DV, Eastman HB, Owen CB, Roman MM, Friedman J, Zabriskie JB, Peterson DL, Pearson GR, Whitman JE. Frequent HHV-6 reactivation in multiple sclerosis (MS) and chronic fatigue syndrome (CFS) patients. J Clin Virol. 2000;16:179-91.

23. McGarry F, Gow J, Behan PO. Enterovirus in the chronic fatigue syndrome. Ann Intern Med. 1994;120:972-3.
24. Holmes MJ, Diack DS, Easingwood RA, Cross JP, Carlisle B. Electron microscopic immunocytological profiles in chronic fatigue syndrome. J Psychiatr Res. 1997;31:115-22.

25. Nasralla M, Haier J, Nicolson GL. Multiple mycoplasmal infections detected in blood of patients with chronic fatigue syndrome and/or fibromyalgia syndrome. Eur J Clin Microbiol Infect Dis. 1999;1 18:859-65.

26. Komaroff AL. Is human herpesvirus- 6 a trigger for chronic fatigue syndrome? J Clin Virol. 2006;37(Suppl 1):S39-46.

27. Morinet F, Corruble E. Chronic fatigue syndrome and viral infections. In: Snell CR, editor. An international perspective on the future of research in chronic fatigue syndrome. Croatia: InTech; 2012. p. 1-12.

28. De Bolle L, Van Loon J, De Clercq E, Naesens L. Quantitative analysis of human herpesvirus 6 cell tropism. J Med Virol. 2005;75:76-85.

29. Sotzny F, Blanco J, Capelli E, Castro-Marrero J, Steiner S, Murovska M, Scheibenbogen C, European Network on MC. Myalgic encephalomyelitis/chronic fatique syndrome_-evidence for an autoimmune disease. Autoimmun Rev. 2018;17:601-9.

30. Roizman B, Carmichael LE, Deinhardt F, de The G, Nahmias AJ, Plowright W, Rapp F, Sheldrick P, Takahashi M, Wolf K. Herpesviridae. Definition, provisional nomenclature, and taxonomy. The Herpesvirus Study Group, the International Committee on Taxonomy of Viruses. Intervirology. 1981:16:201-17.

31. Salahuddin SZ, Ablashi DV, Markham PD, Josephs SF, Sturzenegger S, Kaplan M, Halligan G, Biberfeld P, Wong-Staal F, Kramarsky B, et al. Isolation of a new virus, HBLV, in patients with lymphoproliferative disorders. Science. 1986;234:596-601.

32. Frenkel N, Schirmer EC, Wyatt LS, Katsafanas G, Roffman E, Danovich $\mathrm{RM}$, June $\mathrm{CH}$. Isolation of a new herpesvirus from human CD4+T cells. Proc Natl Acad Sci USA. 1990;87:748-52.

33. Yamanishi K, Okuno T, Shiraki K, Takahashi M, Kondo T, Asano Y, Kurata T. Identification of human herpesvirus-6 as a causal agent for exanthem subitum. Lancet. 1988;1:1065-7.

34. Kondo K, Hayakawa Y, Mori H, Sato S, Kondo T, Takahashi K, Minamishima Y, Takahashi M, Yamanishi K. Detection by polymerase chain reaction amplification of human herpesvirus 6 DNA in peripheral blood of patients with exanthem subitum. J Clin Microbiol. 1990;28:970-4.

35. Caselli E, Di Luca D. Molecular biology and clinical associations of Roseoloviruses human herpesvirus 6 and human herpesvirus 7. New Microbiol. 2007;30:173-87.

36. Bassig BA, Willhauck-Fleckenstein M, Shu XO, Koh WP, Gao YT, Purdue MP, Xiang YB, Adams-Haduch J, Wang R, Brenner N, et al. Serologic markers of viral infection and risk of non-Hodgkin lymphoma: a pooled study of three prospective cohorts in China and Singapore. Int $J$ Cancer. 2018;143:570-9.

37. Kaufer BB, Flamand L. Chromosomally integrated HHV-6: impact on virus, cell and organismal biology. Curr Opin Virol. 2014;9C:111-8.

38. Prusty BK, Krohne G, Rudel T. Reactivation of chromosomally integrated human herpesvirus- 6 by telomeric circle formation. PLoS Genet. 2013;9:e1004033.

39. Prusty BK, Gulve N, Rasa S, Murovska M, Hernandez PC, Ablashi DV. Possible chromosomal and germline integration of human herpesvirus $7 . J$ Gen Virol. 2017;98:266-74

40. Dockrell DH. Human herpesvirus 6: molecular biology and clinical features. J Med Microbiol. 2003;52:5-18.

41. Mirandola P, Sponzilli I, Solenghi E, Micheloni C, Rinaldi L, Gobbi G, Vitale M. Down-regulation of human leukocyte antigen class I and II and beta 2-microglobulin expression in human herpesvirus-7-infected cells. J Infect Dis. 2006;193:917-26.

42. Dagna L, Pritchett JC, Lusso P. Immunomodulation and immunosuppression by human herpesvirus 6A and 6B. Future Virol. 2013:8:273-87.

43. Katsafanas GC, Schirmer EC, Wyatt LS, Frenkel N. In vitro activation of human herpesviruses 6 and 7 from latency. Proc Natl Acad Sci USA. 1996;93:9788-92.

44. Boutolleau D, Fernandez C, Andre E, Imbert-Marcille BM, Milpied N, Agut H, Gautheret-Dejean A. Human herpesvirus (HHV)-6 and HHV-7: two closely related viruses with different infection profiles in stem cell transplantation recipients. J Infect Dis. 2003;187:179-86.

45. Hall CB, Caserta MT, Schnabel KC, McDermott MP, Lofthus GK, Carnahan JA, Gilbert LM, Dewhurst S. Characteristics and acquisition of human herpesvirus (HHV) 7 infections in relation to infection with HHV-6. J Infect Dis. 2006:193:1063-9. 
46. Chapenko S, Millers A, Nora Z, Logina I, Kukaine R, Murovska M. Correlation between HHV- 6 reactivation and multiple sclerosis disease activity. J Med Virol. 2003;69:111-7.

47. Seeley WW, Marty FM, Holmes TM, Upchurch K, Soiffer RJ, Antin JH, Baden LR, Bromfield EB. Post-transplant acute limbic encephalitis: clinical features and relationship to HHV6. Neurology. 2007;69:156-65.

48. Arbuckle JH, Medveczky MM, Luka J, Hadley SH, Luegmayr A, Ablashi D, Lund TC, Tolar J, De Meirleir K, Montoya JG, et al. The latent human herpesvirus-6A genome specifically integrates in telomeres of human chromosomes in vivo and in vitro. Proc Natl Acad Sci USA 2010;107:5563-8.

49. Mardivirin L, Descamps V, Lacroix A, Delebassee S, Ranger-Rogez S. Early effects of drugs responsible for DRESS on HHV-6 replication in vitro. J Clin Virol. 2009;46:300-2.

50. Mardivirin L, Valeyrie-Allanore L, Branlant-Redon E, Beneton N, Jidar K, Barbaud A, Crickx B, Ranger-Rogez S, Descamps V. Amoxicillin-induced flare in patients with DRESS (Drug Reaction with Eosinophilia and Systemic Symptoms): report of seven cases and demonstration of a direct effect of amoxicillin on Human Herpesvirus 6 replication in vitro. Eur J Dermatol. 2010;20:68-73.

51. Martinez A, Alvarez-Lafuente R, Mas A, Bartolome M, Garcia-Montojo M, de Las Heras V, de la Concha EG, Arroyo R, Urcelay E. Environment-gene interaction in multiple sclerosis: human herpesvirus 6 and MHC2TA. Hum Immunol. 2007;68:685-9.

52. Lusso P, Crowley RW, Malnati MS, Di Serio C, Ponzoni M, Biancotto A, Markham PD, Gallo RC. Human herpesvirus 6A accelerates AIDS progression in macaques. Proc Natl Acad Sci USA. 2007;104:5067-72.

53. Gorniak RJ, Young GS, Wiese DE, Marty FM, Schwartz RB. MR imaging of human herpesvirus-6-associated encephalitis in 4 patients with anterograde amnesia after allogeneic hematopoietic stem-cell transplantation. AJNR Am J Neuroradiol. 2006:27:887-91.

54. Chevret L, Boutolleau D, Halimi-Idri N, Branchereau S, Baujard C, Fabre M, Gautheret-Dejean A, Debray D. Human herpesvirus-6 infection: a prospective study evaluating HHV-6 DNA levels in liver from children with acute liver failure. J Med Virol. 2008;80:1051-7.

55. Ablashi DV, Salahuddin SZ, Josephs SF, Balachandran N, Krueger GR, Gallo RC. Human herpesvirus-6 (HHV-6) (short review). In Vivo. 1991;5:193-9.

56. Komaroff AL. Chronic fatigue syndromes: relationship to chronic viral infections. J Virol Methods. 1988;21:3-10.

57. Ablashi DV. Viral studies of chronic fatigue syndrome. Clin Infect Dis. 1994:18(Suppl 1):S130-3.

58. Josephs SF, Henry B, Balachandran N, Strayer D, Peterson D, Komaroff AL, Ablashi DV. HHV-6 reactivation in chronic fatigue syndrome. Lancet. 1991;337:1346-7.

59. Patnaik M, Komaroff AL, Conley E, Ojo-Amaize EA, Peter JB. Prevalence of IgM antibodies to human herpesvirus 6 early antigen (p41/38) in patients with chronic fatigue syndrome. J Infect Dis. 1995;172:1364-7.

60. Secchiero P, Carrigan DR, Asano Y, Benedetti L, Crowley RW, Komaroff AL, Gallo RC, Lusso P. Detection of human herpesvirus 6 in plasma of children with primary infection and immunosuppressed patients by polymerase chain reaction. J Infect Dis. 1995;171:273-80.

61. Koelle DM, Barcy S, Huang ML, Ashley RL, Corey L, Zeh J, Ashton S, Buchwald D. Markers of viral infection in monozygotic twins discordant for chronic fatigue syndrome. Clin Infect Dis. 2002;35:518-25.

62. Chapenko S, Krumina A, Logina I, Rasa S, Chistjakovs M, Sultanova A, Viksna L, Murovska M. Association of active human herpesvirus-6, -7 and parvovirus b19 infection with clinical outcomes in patients with myalgic encephalomyelitis/chronic fatigue syndrome. Adv Virol. 2012:2012:205085.

63. Sairenji T, Yamanishi K, Tachibana Y, Bertoni G, Kurata T. Antibody responses to Epstein-Barr virus, human herpesvirus 6 and human herpesvirus 7 in patients with chronic fatigue syndrome. Intervirology. 1995;38:269-73.

64. Chapenko S, Krumina A, Kozireva S, Nora Z, Sultanova A, Viksna L, Murovska M. Activation of human herpesviruses 6 and 7 in patients with chronic fatigue syndrome. J Clin Virol. 2006;37(Suppl 1):S47-51.

65. Di Luca D, Zorzenon M, Mirandola P, Colle R, Botta GA, Cassai E. Human herpesvirus 6 and human herpesvirus 7 in chronic fatigue syndrome. J Clin Microbiol. 1995;33:1660-1.
66. Wallace HL 2nd, Natelson B, Gause W, Hay J. Human herpesviruses in chronic fatigue syndrome. Clin Diagn Lab Immunol. 1999;6:216-23.

67. Reeves WC, Stamey FR, Black JB, Mawle AC, Stewart JA, Pellett PE. Human herpesviruses 6 and 7 in chronic fatigue syndrome: a casecontrol study. Clin Infect Dis. 2000;31:48-52.

68. Fremont M, Metzger K, Rady H, Hulstaert J, De Meirleir K. Detection of herpesviruses and parvovirus B19 in gastric and intestinal mucosa of chronic fatigue syndrome patients. In Vivo. 2009;23:209-13.

69. Oakes B, Hoagland-Henefield M, Komaroff AL, Erickson JL, Huber BT. Human endogenous retrovirus-K18 superantigen expression and human herpesvirus- 6 and human herpesvirus-7 viral loads in chronic fatigue patients. Clin Infect Dis. 2013;56:1394-400.

70. Aoki R, Kobayashi N, Suzuki G, Kuratsune H, Shimada K, Oka N, Takahashi M, Yamadera W, Iwashita M, Tokuno S, et al. Human herpesvirus 6 and 7 are biomarkers for fatigue, which distinguish between physiological fatigue and pathological fatigue. Biochem Biophys Res Commun. 2016;478:424-30.

71. Lerner AM, Beqaj SH, Deeter RG, Fitzgerald JT. IgM serum antibodies to Epstein-Barr virus are uniquely present in a subset of patients with the chronic fatigue syndrome. In Vivo. 2004;18:101-6.

72. Loebel M, Strohschein K, Giannini C, Koelsch U, Bauer S, Doebis C, Thomas S, Unterwalder N, von Baehr V, Reinke P, et al. Deficient EBV-specific B- and T-cell response in patients with chronic fatigue syndrome. PLoS ONE. 2014;9:e85387.

73. Loebel M, Eckey M, Sotzny F, Hahn E, Bauer S, Grabowski P, Zerweck J, Holenya P, Hanitsch LG, Wittke K, et al. Serological profiling of the EBV immune response in Chronic Fatigue Syndrome using a peptide microarray. PLOS ONE. 2017;12:e0179124.

74. Manian FA. Simultaneous measurement of antibodies to Epstein-Barr virus, human herpesvirus 6, herpes simplex virus types 1 and 2, and 14 enteroviruses in chronic fatigue syndrome: is there evidence of activation of a nonspecific polyclonal immune response? Clin Infect Dis. 1994;19:448-53.

75. Levine PH, Jacobson S, Pocinki AG, Cheney P, Peterson D, Connelly RR, Weil R, Robinson SM, Ablashi DV, Salahuddin SZ, et al. Clinical, epidemiologic, and virologic studies in four clusters of the chronic fatigue syndrome. Arch Intern Med. 1992;152:1611-6.

76. Landay AL, Jessop C, Lennette ET, Levy JA. Chronic fatigue syndrome: clinical condition associated with immune activation. Lancet. 1991:338:707-12.

77. Gupta S, Vayuvegula B. A comprehensive immunological analysis in chronic fatigue syndrome. Scand J Immunol. 1991;33:319-27.

78. Zorzenon M, Rukh G, Botta GA, Colle R, Barsanti LA, Ceccherini-Nelli L. Active HHV-6 infection in chronic fatigue syndrome patients from Italy: new data. J Chronic Fatigue Syndr. 1996;2:3-12.

79. Buchwald D, Ashley RL, Pearlman T, Kith P, Komaroff AL. Viral serologies in patients with chronic fatigue and chronic fatigue syndrome. J Med Virol. 1996;50:25-30.

80. Zhang L, Gough J, Christmas D, Mattey DL, Richards SC, Main J, Enlander D, Honeybourne D, Ayres JG, Nutt DJ, Kerr JR. Microbial infections in eight genomic subtypes of chronic fatigue syndrome/myalgic encephalomyelitis. J Clin Pathol. 2010;63:156-64.

81. Wagner M, Krueger GR, Ablashi D, Whitman JE. Chronic fatigue syndrome (CFS): a critical evaluation of testing for active human herpesvirus-6 (HHV-6) infection. J Chronic Fatigue Syndr. 1996;2:3-16.

82. Hickie I, Davenport T, Wakefield D, Vollmer-Conna U, Cameron B, Vernon SD, Reeves WC, Lloyd A. Post-infective and chronic fatigue syndromes precipitated by viral and non-viral pathogens: prospective cohort study. BMJ. 2006;333:575.

83. Cameron B, Flamand L, Juwana H, Middeldorp J, Naing Z, Rawlinson W, Ablashi D, Lloyd A. Serological and virological investigation of the role of the herpesviruses EBV, CMV and HHV-6 in post-infective fatigue syndrome. J Med Virol. 2010;82:1684-8.

84. Lerner AM, Ariza ME, Williams M, Jason L, Beqaj S, Fitzgerald JT, Lemeshow S, Glaser R. Antibody to Epstein-Barr virus deoxyuridine triphosphate nucleotidohydrolase and deoxyribonucleotide polymerase in a chronic fatigue syndrome subset. PLoS ONE. 2012;7:e47891.

85. Halpin P, Williams MV, Klimas NG, Fletcher MA, Barnes Z, Ariza ME. Myalgic encephalomyelitis/chronic fatigue syndrome and gulf war illness patients exhibit increased humoral responses to the 
herpesviruses-encoded dUTPase: implications in disease pathophysiology. J Med Virol. 2017;89:1636-45.

86. Lerner AM, Beqaj SH, Deeter RG, Fitzgerald JT. IgM serum antibodies to human cytomegalovirus nonstructural gene products p52 and CM2(UL44 and UL57) are uniquely present in a subset of patients with chronic fatigue syndrome. In Vivo. 2002;16:153-9.

87. Rabausch-Starz I, Schwaiger A, Grunewald K, Muller-Hermelink HK, Neu N. Persistence of virus and viral genome in myocardium after coxsackievirus B3-induced murine myocarditis. Clin Exp Immunol. 1994;96:69-74.

88. Andreoletti L, Hober D, Becquart P, Belaich S, Copin MC, Lambert V, Wattre P. Experimental CVB3-induced chronic myocarditis in two murine strains: evidence of interrelationships between virus replication and myocardial damage in persistent cardiac infection. J Med Virol. 1997;52:206-14.

89. Kandolf R, Sauter M, Aepinus C, Schnorr JJ, Selinka HC, Klingel K. Mechanisms and consequences of enterovirus persistence in cardiac myocytes and cells of the immune system. Virus Res. 1999;62:149-58.

90. Frisk G. Mechanisms of chronic enteroviral persistence in tissue. Curr Opin Infect Dis. 2001;14:251-6.

91. Clements GB, McGarry F, Nairn C, Galbraith DN. Detection of enterovirus-specific RNA in serum: the relationship to chronic fatigue. J Med Virol. 1995;45:156-61.

92. Nairn C, Galbraith DN, Clements GB. Comparison of coxsackie B neutralisation and enteroviral PCR in chronic fatigue patients. J Med Virol. 1995;46:310-3.

93. Gow JW, Behan WM, Clements GB, Woodall C, Riding M, Behan PO. Enteroviral RNA sequences detected by polymerase chain reaction in muscle of patients with postviral fatigue syndrome. BMJ. 1991;302:692-6.

94. Lane RJ, Soteriou BA, Zhang H, Archard LC. Enterovirus related metabolic myopathy: a postviral fatigue syndrome. J Neurol Neurosurg Psychiatry. 2003;74:1382-6.

95. Bowles NE, Bayston TA, Zhang HY, Doyle D, Lane RJ, Cunningham L, Archard LC. Persistence of enterovirus RNA in muscle biopsy samples suggests that some cases of chronic fatigue syndrome result from a previous, inflammatory viral myopathy. J Med. 1993;24:145-60.

96. Cunningham L, Bowles NE, Lane RJ, Dubowitz V, Archard LC. Persistence of enteroviral RNA in chronic fatigue syndrome is associated with the abnormal production of equal amounts of positive and negative strands of enteroviral RNA. J Gen Virol. 1990;71 (Pt 6):1399-402.

97. Douche-Aourik F, Berlier W, Feasson L, Bourlet T, Harrath R, Omar S, Grattard F, Denis C, Pozzetto B. Detection of enterovirus in human skeletal muscle from patients with chronic inflammatory muscle disease or fibromyalgia and healthy subjects. J Med Virol. 2003;71:540-7.

98. Chia JK, Chia AY. Chronic fatigue syndrome is associated with chronic enterovirus infection of the stomach. J Clin Pathol. 2008:61:43-8.

99. Chia J, Chia A, Voeller M, Lee T, Chang R. Acute enterovirus infection followed by myalgic encephalomyelitis/chronic fatigue syndrome (ME/ CFS) and viral persistence. J Clin Pathol. 2010;63:165-8.

100. Galbraith DN, Nairn C, Clements GB. Phylogenetic analysis of short enteroviral sequences from patients with chronic fatigue syndrome. J Gen Virol. 1995;76(Pt 7):1701-7.

101. Galbraith DN, Nairn C, Clements GB. Evidence for enteroviral persistence in humans. J Gen Virol. 1997:78(Pt 2):307-12.

102. Chia JK, Chia AY. Ribavirin and interferon-a for the treatment of patients with chronic fatigue syndrome associated with persistent coxsackievirus b infection: a preliminary observation. J Appl Res. 2004;4:286-92.

103. Swanink CM, Melchers WJ, van der Meer JW, Vercoulen JH, Bleijenberg $\mathrm{G}$, Fennis JF, Galama JM. Enteroviruses and the chronic fatigue syndrome. Clin Infect Dis. 1994;19:860-4.

104. Lindh G, Samuelson A, Hedlund KO, Evengard B, Lindquist L, Ehrnst A. No findings of enteroviruses in Swedish patients with chronic fatigue syndrome. Scand J Infect Dis. 1996;28:305-7.

105. McArdle A, McArdle F, Jackson MJ, Page SF, Fahal I, Edwards RH. Investigation by polymerase chain reaction of enteroviral infection in patients with chronic fatigue syndrome. Clin Sci (Lond). 1996;90:295-300.

106. Gow JW, Behan WM, Simpson K, McGarry F, Keir S, Behan PO. Studies on enterovirus in patients with chronic fatigue syndrome. Clin Infect Dis. 1994;18(Suppl 1):S126-9.
107. Cossart YE, Field AM, Cant B, Widdows D. Parvovirus-like particles in human sera. Lancet. 1975;1:72-3.

108. Pattison JR, Jones SE, Hodgson J, Davis LR, White JM, Stroud CE, Murtaza L. Parvovirus infections and hypoplastic crisis in sickle-cell anaemia. Lancet. 1981;1:664-5.

109. Kerr JR. Pathogenesis of human parvovirus B19 in rheumatic disease. Ann Rheum Dis. 2000:59:672-83.

110. Kerr JR. The role of parvovirus B19 in the pathogenesis of autoimmunity and autoimmune disease. J Clin Pathol. 2016:69:279-91.

111. Barah F, Whiteside S, Batista S, Morris J. Neurological aspects of human parvovirus B19 infection: a systematic review. Rev Med Virol. 2014;24:154-68.

112. Kerr JR, Tyrrell DA. Cytokines in parvovirus B19 infection as an aid to understanding chronic fatigue syndrome. Curr Pain Headache Rep. 2003;7:333-41.

113. Ilaria RL Jr, Komaroff AL, Fagioli LR, Moloney WC, True CA, Naides SJ. Absence of parvovirus B19 infection in chronic fatigue syndrome. Arthritis Rheum. 1995;38:638-41.

114. Kerr JR, Mattey DL. Preexisting psychological stress predicts acute and chronic fatigue and arthritis following symptomatic parvovirus B19 infection. Clin Infect Dis. 2008;46:e83-7.

115. Kato YH, Yamate M, Tsujikawa M, Nishigaki H, Tanaka Y, Yunoki M, Kuratsune $\mathrm{H}$, Watanabe $\mathrm{Y}$, Ikuta K. No apparent difference in the prevalence of parvovirus B19 infection between chronic fatigue syndrome patients and healthy controls in Japan. J Clin Virol. 2009;44:246-7.

116. Kerr JR, Gough J, Richards SC, Main J, Enlander D, McCreary M, Komaroff AL, Chia JK. Antibody to parvovirus B19 nonstructural protein is associated with chronic arthralgia in patients with chronic fatigue syndrome/ myalgic encephalomyelitis. J Gen Virol. 2010;91:893-7.

117. Urisman A, Molinaro RJ, Fischer N, Plummer SJ, Casey G, Klein EA, Malathi K, Magi-Galluzzi C, Tubbs RR, Ganem D, et al. Identification of a novel Gammaretrovirus in prostate tumors of patients homozygous for R462Q RNASEL variant. PLoS Pathog. 2006;2:e25.

118. Paprotka T, Delviks-Frankenberry KA, Cingoz O, Martinez A, Kung HJ, Tepper CG, Hu WS, Fivash MJ Jr, Coffin JM, Pathak VK. Recombinant origin of the retrovirus XMRV. Science. 2011;333:97-101.

119. Demettre E, Bastide L, D'Haese A, De Smet K, De Meirleir K, Tiev KP, Englebienne P, Lebleu B. Ribonuclease L proteolysis in peripheral blood mononuclear cells of chronic fatigue syndrome patients. J Biol Chem. 2002;277:35746-51

120. Lombardi VC, Ruscetti FW, Das Gupta J, Pfost MA, Hagen KS, Peterson DL, Ruscetti SK, Bagni RK, Petrow-Sadowski C, Gold B, et al. Detection of an infectious retrovirus, XMRV, in blood cells of patients with chronic fatigue syndrome. Science. 2009;326:585-9.

121. Alberts B. Retraction. Science. 2011;334:1636

122. Lo SC, Pripuzova N, Li B, Komaroff AL, Hung GC, Wang R, Alter HJ. Detection of MLV-related virus gene sequences in blood of patients with chronic fatigue syndrome and healthy blood donors. Proc Natl Acad Sci USA. 2010;107:15874-9.

123. Erlwein O, Kaye S, McClure MO, Weber J, Wills G, Collier D, Wessely S, Cleare A. Failure to detect the novel retrovirus XMRV in chronic fatigue syndrome. PLoS ONE. 2010;5:e8519.

124. Hohn O, Strohschein K, Brandt AU, Seeher S, Klein S, Kurth R, Paul F, Meisel C, Scheibenbogen C, Bannert N. No evidence for XMRV in German CFS and MS patients with fatigue despite the ability of the virus to infect human blood cells in vitro. PLoS ONE. 2010;5:e15632.

125. Hong P, Li J, Li Y. Failure to detect Xenotropic murine leukaemia virusrelated virus in Chinese patients with chronic fatigue syndrome. Virol J. 2010;7:224.

126. Switzer WM, Jia H, Hohn O, Zheng H, Tang S, Shankar A, Bannert N, Simmons G, Hendry RM, Falkenberg VR, et al. Absence of evidence of Xenotropic murine leukemia virus-related virus infection in persons with chronic fatigue syndrome and healthy controls in the United States. Retrovirology. 2010;7:57.

127. Elfaitouri A, Shao X, Mattsson Ulfstedt J, Muradrasoli S, Bolin Wiener A, Golbob S, Ohrmalm C, Matousek M, Zachrisson O, Gottfries CG, Blomberg J. Murine gammaretrovirus group G3 was not found in Swedish patients with myalgic encephalomyelitis/chronic fatigue syndrome and fibromyalgia. PLoS ONE. 2011;6:e24602.

128. Groom HC, Boucherit VC, Makinson K, Randal E, Baptista S, Hagan S, Gow JW, Mattes FM, Breuer J, Kerr JR, et al. Absence of Xenotropic 
murine leukaemia virus-related virus in UK patients with chronic fatigue syndrome. Retrovirology. 2010;7:10.

129. Furuta RA, Miyazawa T, Sugiyama T, Kuratsune H, Ikeda Y, Sato E, Misawa N, Nakatomi Y, Sakuma R, Yasui K, et al. No association of Xenotropic murine leukemia virus-related virus with prostate cancer or chronic fatigue syndrome in Japan. Retrovirology. 2011;8:20.

130. Satterfield BC, Garcia RA, Jia H, Tang S, Zheng H, Switzer WM. Serologic and PCR testing of persons with chronic fatigue syndrome in the United States shows no association with xenotropic or polytropic murine leukemia virus-related viruses. Retrovirology. 2011;8:12.

131. Steffen I, Tyrrell DL, Stein E, Montalvo L, Lee TH, Zhou Y, Lu K, Switzer WM, Tang S, Jia H, et al. No evidence for XMRV nucleic acids, infectious virus or anti-XMRV antibodies in Canadian patients with chronic fatigue syndrome. PLoS ONE. 2011;6:e27870.

132. van Kuppeveld FJ, de Jong AS, Lanke KH, Verhaegh GW, Melchers WJ, Swanink CM, Bleijenberg G, Netea MG, Galama JM, van der Meer JW. Prevalence of Xenotropic murine leukaemia virus-related virus in patients with chronic fatigue syndrome in the Netherlands: retrospective analysis of samples from an established cohort. BMJ. 2010;340:c1018.

133. Alter HJ, Mikovits JA, Switzer WM, Ruscetti FW, Lo SC, Klimas N, Komaroff AL, Montoya JG, Bateman L, Levine S, et al. A multicenter blinded analysis indicates no association between chronic fatigue syndrome/myalgic encephalomyelitis and either Xenotropic murine leukemia virus-related virus or polytropic murine leukemia virus. MBio. 2012;3:e00266.

134. Rasa S, Nora-Krukle Z, Chapenko S, Krumina A, Roga S, Murovska M. No evidence of XMRV provirus sequences in patients with myalgic encephalomyelitis/chronic fatigue syndrome and individuals with unspecified encephalopathy. New Microbiol. 2014;37:17-24.

135. Panelli S, Lorusso L, Balestrieri A, Lupo G, Capelli E. XMRV and Public Health: the retroviral genome is not a suitable template for diagnostic $\mathrm{pcr}$, and its association with myalgic encephalomyelitis/chronic fatigue syndrome appears unreliable. Front Public Health. 2017;5:108.

136. Knox K, Carrigan D, Simmons G, Teque F, Zhou Y, Hackett J Jr, Qiu X, Luk KC, Schochetman G, Knox A, et al. No evidence of murine-like gammaretroviruses in CFS patients previously identified as XMRV-infected. Science. 2011;333:94-7.

137. Smith RA. Contamination of clinical specimens with MLV-encoding nucleic acids: implications for XMRV and other candidate human retroviruses. Retrovirology. 2010;7:112.

138. Katzourakis A, Hue S, Kellam P, Towers GJ. Phylogenetic analysis of murine leukemia virus sequences from longitudinally sampled chronic fatigue syndrome patients suggests PCR contamination rather than viral evolution. J Virol. 2011;85:10909-13.

139. Shin CH, Bateman L, Schlaberg R, Bunker AM, Leonard CJ, Hughen RW, Light AR, Light KC, Singh IR. Absence of XMRV retrovirus and other murine leukemia virus-related viruses in patients with chronic fatigue syndrome. J Virol. 2011;85:7195-202.

140. Irlbeck DM, Vernon SD, McCleary KK, Bateman L, Klimas NG, Lapp CW, Peterson DL, Brown JR, Remlinger KS, Wilfret DA, Gerondelis P. No association found between the detection of either Xenotropic murine leukemia virus-related virus or polytropic murine leukemia virus and chronic fatique syndrome in a blinded, multi-site, prospective study by the establishment and use of the SolveCFS BioBank. BMC Res Notes. 2014;7:461

141. Kearney MF, Spindler J, Wiegand A, Shao W, Anderson EM, Maldarelli F, Ruscetti FW, Mellors JW, Hughes SH, Le Grice SF, Coffin JM. Multiple sources of contamination in samples from patients reported to have XMRV infection. PLoS ONE. 2012;7:e30889.

142. Johnson AD, Cohn CS. Xenotropic murine leukemia virus-related virus (XMRV) and the safety of the blood supply. Clin Microbiol Rev. 2016;29:749-57.

143. Gow JW, Simpson K, Schliephake A, Behan WM, Morrison LJ, Cavanagh $\mathrm{H}$, Rethwilm A, Behan PO. Search for retrovirus in the chronic fatigue syndrome. J Clin Pathol. 1992;45:1058-61.

144. Khan AS, Heneine WM, Chapman LE, Gary HE Jr, Woods TC, Folks TM, Schonberger LB. Assessment of a retrovirus sequence and other possible risk factors for the chronic fatigue syndrome in adults. Ann Intern Med. 1993;118:241-5.

145. Selden SM, Cameron AS. Changing epidemiology of Ross River virus disease in South Australia. Med J Aust. 1996:165:313-7.
146. Lidbury BA, Mahalingam S. Specific ablation of antiviral gene expression in macrophages by antibody-dependent enhancement of Ross River virus infection. J Virol. 2000;74:8376-81.

147. Mahalingam S, Lidbury BA. Suppression of lipopolysaccharide-induced antiviral transcription factor (STAT-1 and NF-kappa B) complexes by antibody-dependent enhancement of macrophage infection by Ross River virus. Proc Natl Acad Sci USA. 2002;99:13819-24.

148. Vollmer-Conna U, Fazou C, Cameron B, Li H, Brennan C, Luck L, Davenport T, Wakefield D, Hickie I, Lloyd A. Production of pro-inflammatory cytokines correlates with the symptoms of acute sickness behaviour in humans. Psychol Med. 2004;34:1289-97.

149. Galbraith S, Cameron B, Li H, Lau D, Vollmer-Conna U, Lloyd AR. Peripheral blood gene expression in postinfective fatigue syndrome following from three different triggering infections. J Infect Dis. 2011;204:1632-40.

150. Cvejic E, Lemon J, Hickie IB, Lloyd AR, Vollmer-Conna U. Neurocognitive disturbances associated with acute infectious mononucleosis, Ross River fever and Q fever: a preliminary investigation of inflammatory and genetic correlates. Brain Behav Immun. 2014;36:207-14.

151. Nijs J, Fremont M. Intracellular immune dysfunction in myalgic encephalomyelitis/chronic fatigue syndrome: state of the art and therapeutic implications. Expert Opin Ther Targets. 2008;12:281-9.

152. Broderick G, Fuite J, Kreitz A, Vernon SD, Klimas N, Fletcher MA. A formal analysis of cytokine networks in chronic fatigue syndrome. Brain Behav Immun. 2010;24:1209-17.

153. Glassford JA. The neuroinflammatory etiopathology of myalgic encephalomyelitis/chronic fatigue syndrome (ME/CFS). Front Physiol. 2017:8:88

154. Sairenji T, Nagata K. Viral infections in chronic fatigue syndrome. Nihon Rinsho. 2007:65:991-6.

155. Patarca R, Sandler D, Walling J, Lunn BC, Fletcher MA. Assessment of immune mediator expression levels in biological fluids and cells: a critical appraisal. Crit Rev Oncog. 1995;6:117-49.

156. Maes M, Twisk FN, Kubera M, Ringel K. Evidence for inflammation and activation of cell-mediated immunity in myalgic encephalomyelitis/ chronic fatigue syndrome (ME/CFS): increased interleukin-1, tumor necrosis factor-alpha, PMN-elastase, lysozyme and neopterin. J Affect Disord. 2012;136:933-9.

157. Yasui M, Yoshimura T, Takeuchi S, Tokizane K, Tsuda M, Inoue K, Kiyama $\mathrm{H}$. A chronic fatigue syndrome model demonstrates mechanical allodynia and muscular hyperalgesia via spinal microglial activation. Glia. 2014:62:1407-17.

158. Tejada-Simon MV, Zang YC, Hong J, Rivera VM, Zhang JZ. Cross-reactivity with myelin basic protein and human herpesvirus-6 in multiple sclerosis. Ann Neurol. 2003;53:189-97.

159. Peng $N$, Yang $X$, Zhu C, Zhou L, Yu H, Li M, Lin Y, Wang $X$, Li Q, She $Y$, et al. MicroRNA-302 cluster downregulates enterovirus 71-induced innate immune response by targeting KPNA2. J Immunol. 2018;201:145-56.

160. Lind K, Svedin E, Domsgen E, Kapell S, Laitinen O, Moll M, FlodstromTullberg M. Coxsackievirus counters the host innate immune response by blocking type III interferon expression. J Gen Virol. 2016;97:1-12.

161. Pathinayake PS, Hsu AC, Wark PA. Innate immunity and immune evasion by enterovirus 71. Viruses. 2015;7:6613-30.

162. Rizzo R, Soffritti I, D'Accolti M, Bortolotti D, Di Luca D, Caselli E. HHV$6 \mathrm{~A} / 6 \mathrm{~B}$ infection of NK cells modulates the expression of mirnas and transcription factors potentially associated to impaired NK activity. Front Microbiol. 2017:8:2143.

163. Prusty BK, Gulve N, Chowdhury SR, Schuster M, Strempel S, Descamps V, Rudel T. HHV-6 encoded small non-coding RNAs define an intermediate and early stage in viral reactivation. npj Genomic Med. 2018;3:25.

164. Schmiedel D, Tai J, Levi-Schaffer F, Dovrat S, Mandelboim O. Human herpesvirus 6B downregulates expression of activating ligands during lytic infection to escape elimination by natural killer cells. J Virol. 2016;90:9608-17.

165. Fan C, Tang Y, Wang J, Xiong F, Guo C, Wang Y, Xiang B, Zhou M, Li X, Wu $X$, et al. The emerging role of Epstein-Barr virus encoded microRNAs in nasopharyngeal carcinoma. J Cancer. 2018;9:2852-64.

166. Hardcastle SL, Brenu EW, Johnston S, Nguyen T, Huth T, Ramos S, Staines D, Marshall-Gradisnik S. Longitudinal analysis of immune abnormalities in varying severities of chronic fatigue syndrome/myalgic encephalomyelitis patients. J Transl Med. 2015;13:299. 
167. Lusso P. HHV-6 and the immune system: mechanisms of immunomodulation and viral escape. J Clin Virol. 2006;37(Suppl 1):S4-10.

168. Sin SH, Dittmer DP. Cytokine homologs of human gammaherpesviruses. J Interferon Cytokine Res. 2012;32:53-9.

169. Odom Cl, Gaston DC, Markert JM, Cassady KA. Human herpesviridae methods of natural killer cell evasion. Adv Virol. 2012;2012:359869.

170. Kemball CC, Harkins S, Whitmire JK, Flynn CT, Feuer R, Whitton JL. Coxsackievirus B3 inhibits antigen presentation in vivo, exerting a profound and selective effect on the MHC class I pathway. PLoS Pathog. 2009;5:e1000618.

171. Kemball CC, Alirezaei M, Whitton JL. Type B coxsackieviruses and their interactions with the innate and adaptive immune systems. Future Microbiol. 2010:5:1329-47.

172. Schneider CL, Hudson AW. The human herpesvirus-7 (HHV-7) U21 immunoevasin subverts NK-mediated cytoxicity through modulation of MICA and MICB. PLoS Pathog. 2011;7:e1002362.

173. Nastke MD, Becerra A, Yin L, Dominguez-Amorocho O, Gibson L, Stern LJ, Calvo-Calle JM. Human CD4+T cell response to human herpesvirus 6. J Virol. 2012;86:4776-92.

174. Kerr JR, Barah F, Mattey DL, Laing I, Hopkins SJ, Hutchinson IV, Tyrrell DA. Circulating tumour necrosis factor-alpha and interferon-gamma are detectable during acute and convalescent parvovirus B19 infection and are associated with prolonged and chronic fatigue. J Gen Virol. 2001;82:3011-9

175. Appel S, Chapman J, Shoenfeld Y. Infection and vaccination in chronic fatigue syndrome: myth or reality? Autoimmunity. 2007;40:48-53.

176. Matano S, Kinoshita H, Tanigawa K, Terahata S, Sugimoto T. Acute parvovirus B19 infection mimicking chronic fatigue syndrome. Intern Med. 2003:42:903-5.

177. Chehadeh W, Alkhabbaz M. Differential TLR7-mediated expression of proinflammatory and antiviral cytokines in response to laboratory and clinical enterovirus strains. Virus Res. 2013;174:88-94.

178. Shang W, Qian S, Fang L, Han Y, Zheng C. Association study of inflammatory cytokine and chemokine expression in hand foot and mouth disease. Oncotarget. 2017;8:79425-32.

179. De Pelsmaeker S, Romero N, Vitale M, Favoreel HW. Herpesvirus evasion of natural killer cells. J Virol. 2018;92:e02105.

180. Filler K, Lyon D, Bennett J, McCain N, Elswick R, Lukkahatai N, Saligan LN. Association of mitochondrial dysfunction and fatigue: a review of the literature. BBA Clin. 2014;1:12-23.

181. Myhill S, Booth NE, McLaren-Howard J. Chronic fatigue syndrome and mitochondrial dysfunction. Int J Clin Exp Med. 2009;2:1-16.

182. Booth NE, Myhill S, McLaren-Howard J. Mitochondrial dysfunction and the pathophysiology of myalgic encephalomyelitis/chronic fatigue syndrome (ME/CFS). Int J Clin Exp Med. 2012;5:208-20.

183. Meeus M, Nijs J, Hermans L, Goubert D, Calders P. The role of mitochondrial dysfunctions due to oxidative and nitrosative stress in the chronic pain or chronic fatigue syndromes and fibromyalgia patients: peripheral and central mechanisms as therapeutic targets? Expert Opin Ther Targets. 2013;17:1081-9.

184. Vogt $H$, Ulvestad E, Wyller VB. Metabolic features of chronic fatigue syndrome revisited. Proc Natl Acad Sci USA. 2016;113:E7140-1.

185. Naviaux RK, Naviaux JC, Li K, Bright AT, Alaynick WA, Wang L, Baxter A, Nathan N, Anderson W, Gordon E. Metabolic features of chronic fatigue syndrome. Proc Natl Acad Sci USA. 2016;113:E5472-80.

186. Hanson MR, Gu Z, Keinan A, Ye K, Germain A, Billing-Ross P. Association of mitochondrial DNA variants with myalgic encephalomyelitis/chronic fatigue syndrome (ME/CFS) symptoms. J Transl Med. 2016;14:342.

187. Billing-Ross P, Germain A, Ye K, Keinan A, Gu Z, Hanson MR. Mitochondrial DNA variants correlate with symptoms in myalgic encephalomyelitis/chronic fatigue syndrome. J Transl Med. 2016;14:19.

188. Murata T, Goshima F, Daikoku T, Inagaki-Ohara K, Takakuwa H, Kato K, Nishiyama Y. Mitochondrial distribution and function in herpes simplex virus-infected cells. J Gen Virol. 2000;81:401-6.

189. Aubert M, Chen Z, Lang R, Dang CH, Fowler C, Sloan DD, Jerome KR. The antiapoptotic herpes simplex virus glycoprotein J localizes to multiple cellular organelles and induces reactive oxygen species formation. J Virol. 2008:82:617-29.

190. Saffran HA, Pare JM, Corcoran JA, Weller SK, Smiley JR. Herpes simplex virus eliminates host mitochondrial DNA. EMBO Rep. 2007:8:188-93.
191. Vernon SD, Whistler T, Cameron B, Hickie IB, Reeves WC, Lloyd A. Preliminary evidence of mitochondrial dysfunction associated with post-infective fatigue after acute infection with Epstein Barr virus. BMC Infect Dis. 2006;6:15.

192. Pal AD, Basak NP, Banerjee AS, Banerjee S. Epstein-Barr virus latent membrane protein-2A alters mitochondrial dynamics promoting cellular migration mediated by Notch signaling pathway. Carcinogenesis. 2014;35:1592-601.

193. Wiedmer A, Wang P, Zhou J, Rennekamp AJ, Tiranti V, Zeviani M, Lieberman PM. Epstein-Barr virus immediate-early protein Zta co-opts mitochondrial single-stranded DNA binding protein to promote viral and inhibit mitochondrial DNA replication. J Virol. 2008;82:4647-55.

194. Yeo WM, Isegawa Y, Chow VT. The U95 protein of human herpesvirus $6 B$ interacts with human GRIM-19: silencing of U95 expression reduces viral load and abrogates loss of mitochondrial membrane potential. J Virol. 2008;82:1011-20.

195. Prusty BK, Bohme L, Bergmann B, Siegl C, Krause E, Mehlitz A, Rudel T. Imbalanced oxidative stress causes chlamydial persistence during nonproductive human herpes virus co-infection. PLoS ONE. 2012;7:e47427.

196. Li L, Chi J, Zhou F, Guo D, Wang F, Liu G, Zhang C, Yao K. Human herpesvirus $6 \mathrm{~A}$ induces apoptosis of HSB-2 cells via a mitochondrion-related caspase pathway. J Biomed Res. 2010;24:444-51.

197. Lee YL, Liu CE, Cho WL, Kuo CL, Cheng WL, Huang CS, Liu CS. Presence of cytomegalovirus DNA in leucocytes is associated with increased oxidative stress and subclinical atherosclerosis in healthy adults. Biomarkers. 2014;19:109-13.

198. Hwang KY, Choi YB. Modulation of mitochondrial antiviral signaling by human herpesvirus 8 interferon regulatory factor 1. J Virol. 2016;90:506-20.

199. Nykky J, Vuento M, Gilbert L. Role of mitochondria in parvovirus pathology. PLoS ONE. 2014;9:e86124

200. Zhao X, Xiang H, Bai X, Fei N, Huang Y, Song X, Zhang H, Zhang L, Tong D. Porcine parvovirus infection activates mitochondria-mediated apoptotic signaling pathway by inducing ROS accumulation. Virol J. 2016;13:26.

201. Gupta SK, Sahoo AP, Rosh N, Gandham RK, Saxena L, Singh AK, Harish DR, Tiwari AK. Canine parvovirus NS1 induced apoptosis involves mitochondria, accumulation of reactive oxygen species and activation of caspases. Virus Res. 2016;213:46-61.

202. Cheng ML, Weng SF, Kuo CH, Ho HY. Enterovirus 71 induces mitochondrial reactive oxygen species generation that is required for efficient replication. PLOS ONE. 2014:9:e113234.

203. Blomberg J, Gottfries CG, Elfaitouri A, Rizwan M, Rosen A. Infection elicited autoimmunity and myalgic encephalomyelitis/chronic fatigue syndrome: an explanatory model. Front Immunol. 2018;9:229.

204. Montoya JG, Kogelnik AM, Bhangoo M, Lunn MR, Flamand L, Merrihew LE, Watt T, Kubo JT, Paik J, Desai M. Randomized clinical trial to evaluate the efficacy and safety of valganciclovir in a subset of patients with chronic fatigue syndrome. J Med Virol. 2013;85:2101-9.

205. Fluge O, Risa K, Lunde S, Alme K, Rekeland IG, Sapkota D, Kristoffersen EK, Sorland K, Bruland O, Dahl O, Mella O. B-lymphocyte depletion in myalgic encephalopathy/chronic fatigue syndrome. an open-label phase II study with rituximab maintenance treatment. PLoS ONE. 2015;10:e0129898.

206. Scheibenbogen C, Loebel M, Freitag H, Krueger A, Bauer S, Antelmann M, Doehner W, Scherbakov N, Heidecke H, Reinke P, et al. Immunoadsorption to remove ss2 adrenergic receptor antibodies in chronic fatigue syndrome CFS/ME. PLoS ONE. 2018;13:e0193672.

207. Engelmann I, Alidjinou EK, Bertin A, Bossu J, Villenet C, Figeac M, Sane F, Hober D. Persistent coxsackievirus B4 infection induces microRNA dysregulation in human pancreatic cells. Cell Mol Life Sci. 2017;74:3851-61.

208. Burg AR, Das S, Padgett LE, Koenig ZE, Tse HM. Superoxide production by NADPH oxidase intensifies macrophage antiviral responses during diabetogenic coxsackievirus infection. J Immunol. 2018;200:61-70.

209. Lind K, Huhn MH, Flodstrom-Tullberg M. Immunology in the clinic review series; focus on type 1 diabetes and viruses: the innate immune response to enteroviruses and its possible role in regulating type 1 diabetes. Clin Exp Immunol. 2012;168:30-8.

210. Grammatikos AP, Tsokos GC. Immunodeficiency and autoimmunity: lessons from systemic lupus erythematosus. Trends Mol Med. 2012:18:101-8. 
211. Dotta F, Censini S, van Halteren AG, Marselli L, Masini M, Dionisi S, Mosca F, Boggi U, Muda AO, Del Prato S, et al. Coxsackie B4 virus infection of beta cells and natural killer cell insulitis in recent-onset type 1 diabetic patients. Proc Natl Acad Sci U S A. 2007;104:5115-20.

212. Wagner AD, Goronzy JJ, Matteson EL, Weyand CM. Systemic monocyte and T-cell activation in a patient with human parvovirus B19 infection. Mayo Clin Proc. 1995;70:261-5.

213. Xie J, Jiao Y, Qiu Z, Li Q, Li T. Significant elevation of B cells at the acute stage in enterovirus 71-infected children with central nervous system involvement. Scand J Infect Dis. 2010;42:931-5.

214. Caselli E, D'Accolti M, Soffritti I, Zatelli MC, Rossi R, Degli Uberti E, Di Luca D. HHV-6A in vitro infection of thyrocytes and T cells alters the expression of miRNA associated to autoimmune thyroiditis. Virol J. 2017;14:3.

215. Kubo T, Sato K, Kobayashi D, Motegi A, Kobayashi O, Takeshita S, Nonoyama S. A case of HHV-6 associated acute necrotizing encephalopathy with increase of CD56bright NKcells. Scand J Infect Dis. 2006;38:1122-5.

216. Rizzo R, Zatelli MC, Rotola A, Cassai E, Degli Uberti E, Di Luca D, Caselli E. Increase in peripheral CD3-CD56brightCD16- natural killer cells in Hashimoto's thyroiditis associated with HHV-6 infection. Adv Exp Med Biol. 2016;897:113-20.

217. Brenu EW, van Driel ML, Staines DR, Ashton KJ, Hardcastle SL, Keane J, Tajouri L, Peterson D, Ramos SB, Marshall-Gradisnik SM. Longitudinal investigation of natural killer cells and cytokines in chronic fatigue syndrome/myalgic encephalomyelitis. J Transl Med. 2012;10:88.

218. Montoya JG, Holmes TH, Anderson JN, Maecker HT, Rosenberg-Hasson Y, Valencia IJ, Chu L, Younger JW, Tato CM, Davis MM. Cytokine signature associated with disease severity in chronic fatigue syndrome patients. Proc Natl Acad Sci USA. 2017;114:E7150-8.

219. Prinsen H, de Vries IJ, Torensma R, Pots JM, Mulder SF, van Herpen CM, Elving LD, Bleijenberg G, Stelma FF, van Laarhoven HW. Humoral and cellular immune responses after influenza vaccination in patients with chronic fatigue syndrome. BMC Immunol. 2012;13:71.

220. Curriu M, Carrillo J, Massanella M, Rigau J, Alegre J, Puig J, Garcia-Quintana AM, Castro-Marrero J, Negredo E, Clotet B, et al. Screening NK-, B- and T-cell phenotype and function in patients suffering from Chronic Fatigue Syndrome. J Transl Med. 2013;11:68.

221. Rivas JL, Palencia T, Fernandez G, Garcia M. Association of T and NK Cell Phenotype With the Diagnosis of Myalgic Encephalomyelitis/Chronic Fatigue Syndrome (ME/CFS). Front Immunol. 1028;2018:9.

222. Harley JB, Chen X, Pujato M, Miller D, Maddox A, Forney C, Magnusen AF, Lynch A, Chetal K, Yukawa M, et al. Transcription factors operate across disease loci, with EBNA2 implicated in autoimmunity. Nat Genet. 2018:50:699-707.

223. Eriksen W. The spread of EBV to ectopic lymphoid aggregates may be the final common pathway in the pathogenesis of ME/CFS. Med Hypotheses. 2017;102:8-15.

224. VanElzakker MB. Chronic fatigue syndrome from vagus nerve infection: a psychoneuroimmunological hypothesis. Med Hypotheses. 2013;81:414-23.

225. Nakatomi Y, Mizuno K, Ishii A, Wada Y, Tanaka M, Tazawa S, Onoe K, Fukuda S, Kawabe J, Takahashi K, et al. Neuroinflammation in patients with chronic fatigue syndrome/myalgic encephalomyelitis: an (1)(1) C-(R)-PK11195 PET Study. J Nucl Med. 2014;55:945-50.

226. Moreno MA, Or-Geva N, Aftab BT, Khanna R, Croze E, Steinman L, Han $\mathrm{MH}$. Molecular signature of Epstein-Barr virus infection in MS brain lesions. Neurol Neuroimmunol Neuroinflamm. 2018;5:e466.

227. Olsson J, Lovheim H, Honkala E, Karhunen PJ, Elgh F, Kok EH. HSV presence in brains of individuals without dementia: the TASTY brain series. Dis Model Mech. 2016;9:1349-55.

228. Le Guennec L, Mokhtari K, Chauvet D, Dupuis N, Roos-Weil D, Agut H, Leclercq D, Psimaras D, Mayaux J, Demeret S, et al. Human Herpesvirus 6 (HHV-6) necrotizing encephalitis, a rare condition in immunocompromised patients: the importance of brain biopsy associated with HHV-6 testing. J Neurol Sci. 2017;377:112-5.

229. Yoon JY, Danielson B, Mathis D, Karamchandani J, Munoz DG. Cytomegalovirus in the human dentate gyrus and its impact on neural progenitor cells: report of two cases. Clin Neuropathol. 2017;36:240-5.

230. Carpenter JE, Clayton AC, Halling KC, Bonthius DJ, Buckingham EM, Jackson W, Dotzler SM, Card JP, Enquist LW, Grose C. Defensive perimeter in the central nervous system: predominance of astrocytes and astrogliosis during recovery from varicella-zoster virus encephalitis. J Virol. 2016;90:379-91.

231. Dourmashkin RR, McCall SA, Dourmashkin N, Hannah MJ. Virus-like particles and enterovirus antigen found in the brainstem neurons of Parkinson's disease. F1000Res. 2018;7:302.

232. Isumi H, Nunoue T, Nishida A, Takashima S. Fetal brain infection with human parvovirus B19. Pediatr Neurol. 1999:21:661-3.

233. Reynaud JM, Jegou JF, Welsch JC, Horvat B. Human herpesvirus 6A infection in CD46 transgenic mice: viral persistence in the brain and increased production of proinflammatory chemokines via Toll-like receptor 9. J Virol. 2014;88:5421-36.

234. Campbell A, Hogestyn JM, Folts CJ, Lopez B, Proschel C, Mock D, MayerProschel M. Expression of the human herpesvirus $6 \mathrm{~A}$ latency-associated transcript U94A disrupts human oligodendrocyte progenitor migration. Sci Rep. 2017;7:3978.

235. Caselli E, Zatelli MC, Rizzo R, Benedetti S, Martorelli D, Trasforini G, Cassai E, Degli Uberti EC, Luca D, Dolcetti R. Virologic and immunologic evidence supporting an association between HHV-6 and Hashimoto's thyroiditis. PLoS Pathog. 2012;8:e1002951.

236. Sultanova A, Cistjakovs M, Gravelsina S, Chapenko S, Roga S, Cunskis E, Nora-Krukle Z, Groma V, Ventina I, Murovska M. Association of active human herpesvirus-6 (HHV-6) infection with autoimmune thyroid gland diseases. Clin Microbiol Infect. 2017;23(50):e51-5.

237. Broccolo F, Fusetti L, Ceccherini-Nelli L. Possible role of human herpesvirus 6 as a trigger of autoimmune disease. Sci World J. 2013;2013:867389.

238. Broccolo F, Drago F, Cassina G, Fava A, Fusetti L, Matteoli B, CeccheriniNelli L, Sabbadini MG, Lusso P, Parodi A, Malnati MS. Selective reactivation of human herpesvirus 6 in patients with autoimmune connective tissue diseases. J Med Virol. 2013;85:1925-34.

239. Soldan SS, Berti R, Salem N, Secchiero P, Flamand L, Calabresi PA, Brennan MB, Maloni HW, McFarland HF, Lin HC, et al. Association of human herpes virus 6 (HHV-6) with multiple sclerosis: increased IgM response to HHV- 6 early antigen and detection of serum HHV-6 DNA. Nat Med. 1997:3:1394-7.

240. Cirone M, Cuomo L, Zompetta C, Ruggieri S, Frati L, Faggioni A, Ragona G. Human herpesvirus 6 and multiple sclerosis: a study of T cell cross-reactivity to viral and myelin basic protein antigens. J Med Virol. 2002;68:268-72.

241. Niehusmann P, Widman G, Eis-Hubinger AM, Greschus S, Robens BK, Grote A, Becker AJ. Non-paraneoplastic limbic encephalitis and central nervous HHV-6B reactivation: causality or coincidence? Neuropathology. 2016;36:376-80.

242. Descamps V, Ranger-Rogez S. DRESS syndrome. Joint Bone Spine. 2014;81:15-21.

243. Shiohara T, Kano Y. Drug reaction with eosinophilia and systemic symptoms (DRESS): incidence, pathogenesis and management. Expert Opin Drug Saf. 2017;16:139-47.

244. Mine S, Suzuki K, Sato Y, Fukumoto H, Kataoka M, Inoue N, Ohbayashi C, Hasegawa H, Sata T, Fukayama M, Katano H. Evidence for human herpesvirus-6B infection of regulatory T-cells in acute systemic lymphadenitis in an immunocompetent adult with the drug reaction with eosinophilia and systemic symptoms syndrome: a case report. J Clin Virol. 2014;61:448-52.

245. Wang F, Chi J, Peng G, Zhou F, Wang J, Li L, Feng D, Xie F, Gu B, Qin J, et al. Development of virus-specific CD4+ and CD8+ regulatory T cells induced by human herpesvirus 6 infection. J Virol. 2014;88:1011-24.

246. Wang F, Yao K, Yin QZ, Zhou F, Ding CL, Peng GY, Xu J, Chen Y, Feng DJ, $\mathrm{Ma} \mathrm{CL}$, Xu WR. Human herpesvirus-6-specific interleukin 10-producing CD4+T cells suppress the CD4+T-cell response in infected individuals. Microbiol Immunol. 2006;50:787-803.

247. Theorell J, Bileviciute-Ljungar I, Tesi B, Schlums H, Johnsgaard MS, Asadi-Azarbaijani B, Bolle Strand E, Bryceson YT. Unperturbed cytotoxic lymphocyte phenotype and function in myalgic encephalomyelitis/ chronic fatique syndrome patients. Front Immunol. 2017:8:723.

248. Ogawa E, Otaguro S, Murata M, Kainuma M, Sawayama Y, Furusyo N, Hayashi J. Intravenous immunoglobulin therapy for severe arthritis associated with human parvovirus B19 infection. J Infect Chemother. 2008;14:377-82.

249. Cohen BJ, Buckley MM, Clewley JP, Jones VE, Puttick AH, Jacoby RK. Human parvovirus infection in early rheumatoid and inflammatory arthritis. Ann Rheum Dis. 1986;45:832-8. 
250. Kerr JR, Boyd N. Autoantibodies following parvovirus B19 infection. J Infect. 1996;32:41-7.

251. Naciute M, Mieliauskaite D, Rugiene R, Maciunaite G, Mauricas M, Murovska M, Girkontaite I. Parvovirus B19 infection modulates the levels of cytokines in the plasma of rheumatoid arthritis patients. Cytokine. 2017;96:41-8.

252. Hsu TC, Tzang BS, Huang CN, Lee YJ, Liu GY, Chen MC, Tsay GJ. Increased expression and secretion of interleukin-6 in human parvovirus B19 non-structural protein (NS1) transfected COS-7 epithelial cells. Clin Exp Immunol. 2006;144:152-7.

253. Fan MM, Tamburic L, Shippam-Brett C, Zagrodney DB, Astell CR. The small 11-kDa protein from B19 parvovirus binds growth factor receptor-binding protein 2 in vitro in a Src homology 3 domain/liganddependent manner. Virology. 2001;291:285-91.

254. Duechting A, Tschope C, Kaiser H, Lamkemeyer T, Tanaka N, Aberle S, Lang F, Torresi J, Kandolf R, Bock CT. Human parvovirus B19 NS1 protein modulates inflammatory signaling by activation of STAT3/PIAS3 in human endothelial cells. J Virol. 2008;82:7942-52.

255. Tsay GJ, Zouali M. Unscrambling the role of human parvovirus B19 signaling in systemic autoimmunity. Biochem Pharmacol. 2006;72:1453-9.

256. Attard L, Bonvicini F, Gelsomino F, Manfredi R, Cascavilla A, Viale P, Varani S, Gallinella G. Paradoxical response to intravenous immunoglobulin in a case of Parvovirus B19-associated chronic fatigue syndrome. J Clin Virol. 2015:62:54-7.
Ready to submit your research? Choose BMC and benefit from

- fast, convenient online submission

- thorough peer review by experienced researchers in your field

- rapid publication on acceptance

- support for research data, including large and complex data types

- gold Open Access which fosters wider collaboration and increased citations

- maximum visibility for your research: over $100 \mathrm{M}$ website views per year

At BMC, research is always in progress.

Learn more biomedcentral.com/submissions 